\title{
ASPECTOS DE LA SOCIEDAD MURCIANA BAJOMEDIEVAL A TRAVÉS DE LA LITERATURA SINODAL
}

\author{
Jorge Ortuño Molina
}

\section{RESUMEN:}

Los sínodos episcopales son una fuente histórica importantísima para la comprensión de la sociedad medieval. Las constituciones recogen tanto asuntos referentes a la clerecía como los vínculos de los individuos con el resto de la comunidad (matrimonio, relaciones sexuales, trabajo, rentas...). No obstante, ha de tenerse en cuenta el hecho de que existe una sensible diferencia entre la aplicación práctica de la norma o la interpretación personal de los preceptos y lo contenido en ellos: entre los principios básicos de la religión y la religiosidad. A pesar de todo, la Iglesia, como institución creadora de ideología, intenta homogeneizar a toda la sociedad europea con unos valores de sumisión y respeto a un orden social establecido, que coloca a la Iglesia en un estado de privilegio donde ejerce el control mental y corporal de los individuos, en total connivencia con los poderes seculares.

PALABRAS CLAVE: Iglesia, Religiosidad, Religión, Historia Social, Jerarquía, reino de Murcia

\section{ABSTRACT:}

Episcopal synods are a very important historical source to understand the Middle Age society. The articles of the synods include issues concerning priesthood and the relationships of the individual with the community (marriage, sexual relations, kinship, jobs, taxes...). Nevertheless, we must 
considerer that there is a difference between the law and its application, or the personal interpretation of the Religion: between the basic principles of the Religion and the Religiousness. But the Church, as ideology creator, tries to equal the whole european society of the Middle Age in some senses, such as submission and respect for an established social order. In this way, the Church has a privileged place where it controls people's minds and bodies, in total collusion with civil powers.

KEYWORDS: Church, Religiousness, Religion, Social History, Hierarchy, Kingdom of Murcia.

El carácter homogéneo de la sociedad europea occidental en la Edad Media, a pesar de la gran fragmentación política del continente, se debe a la implantación del cristianismo. Las diferencias políticas y enfrentamientos entre reinos encubrían un sentimiento común de pertenencia a una misma comunidad y a la identificación de toda la población con una organización social específica difundida desde la institución eclesiástica. El gran logro de la Iglesia cristiana occidental de mantener una estructura centralizada y fuertemente jerarquizada permitió la difusión de un mensaje común por todo el territorio europeo occidental. Por ello, aunque hablemos de la sociedad murciana en realidad estamos observando unas pautas generales que nos sirven para comprender el comportamiento de otras comunidades tanto en los reinos peninsulares como en el resto de Europa. A través de los sínodos provinciales la Iglesia se dedicaba a transmitir un mensaje que venía emanado desde Roma y que era similar al resto de la Cristiandad. Desde la palestra de las diócesis provinciales se difundía al común la manera de actuación frente al vivir cotidiano.

En la Edad Media Iglesia y sociedad feudal iban estrechamente unidas, pues no en vano desde el siglo XI los principales pensadores eclesiásticos habían conseguido definir y explicitar cómo debía estructurarse la sociedad, convirtiéndose desde ese momento el feudalismo en el sistema dominante. Pero en absoluto resultó un proceso inmediato. Habían sido necesarios más de setecientos años en los que la Iglesia tuvo que adaptarse a la realidad de una sociedad pagana, modificar estos elementos y luego cristianizarlos. En todo este proceso la sociedad también tuvo su papel ya que no fue una recepción pasiva sino que al tiempo que asimilaba el mensaje ideológico introducía rasgos y aspectos que la Iglesia debía aceptar e incorporar. Pero el objetivo se 
cumplió con creces. La Iglesia consiguió controlar el tiempo, tanto el anual como el diurno (trabajo, fiestas...), y el espacio (la cristiandad, la diócesis y la parroquia, sin duda alguna, las demarcaciones más estables con una clara idea de jerarquía). Pero sobre todo, consiguió el control de la enseñanza, tanto la reglada como la catequesis, fundamental en el proceso de creación de la moral cristiana que consiguió penetrar en la conciencia de las gentes y, por lo tanto, en su manera de entender el mundo, aceptarlo y comportarse. Todo ello merced, igualmente, al gran desarrollo de la escritura que la institución eclesiástica consiguió imprimir desde sus orígenes a toda su estructura y que le permitió ser estable ${ }^{1}$.

La introducción de los sacramentos y la idea de la Salvación dotaron a la Iglesia de unos instrumentos básicos para la dominación social. El bautismo introducía al recién nacido en la comunidad, se le hacía cristiano. Luego se conseguía que pensase como cristiano mediante el proceso de catequización, tanto en la familia como en la parroquia, hasta llegar a la confirmación. Como recogen los textos de la Iglesia, para ser cristiano había que tener fe y costumbre $^{2}$. Se debía creer y seguir los rituales y comportamientos que marcaba la institución. Había que casarse por la Iglesia, que de este modo controlaba las relaciones interpersonales y se inventaba nuevos vínculos de pseudoparentesco como los padrinos, la caballería... Había que confesarse y comulgar una vez al año cómo mínimo, es decir, controlaban los actos y la conducta de todo individuo. Había que acudir a misa semanalmente donde se adoctrinaba. Y finalmente había que morir, igual que se nacía, con la sanción de la Iglesia $^{3}$. La institución eclesiástica tenía en sus manos, por ser la administradora de los sacramentos y la única que lo podía hacer, la posibilidad de la salvación de los fieles, a cambio de seguir un cursus honorum ${ }^{4}$. La

1 GUERREAU, A. El Feudalismo. Un horizonte teórico, Barcelona, 1984, págs. 231 y 232 .

2 Biblioteca de El Escorial (en adelante BE), referencia L-II-9, fol. 5r. Manuscrito publicado por SANZ SANCHO, I., Constituciones sinodales de la Diócesis de Cartagena de 1323 a 1409, Murcia, 2003.

3 RODRÍGUEZ LLOPIS, M. y GARCÍA DÍAZ, I., Iglesia y sociedad feudal, Murcia, 1994, pág. 58.

4 MITRE, E. "La preparación ante la muerte en torno a 1300 (algunos elementos configuradores del ars moriendi en occidente)" en La muerte vencida, Valladolid, 1988, pág. 130. 
Iglesia controlaba el tiempo vital del hombre desde su nacimiento hasta su muerte, e incluso más allá.

La literatura sinodal nos permite ir comprendiendo los procedimientos llevados a cabo por la Iglesia para regular a todos los feligreses. Son un claro ejemplo de normas de conducta a seguir, tanto por los laicos como por los seglares, que nos proporcionan una visión sesgada, pero totalmente complementaria y admisible, de la sociedad del medievo. Para la realización de la presente investigación nos hemos valido fundamentalmente del sínodo conservado de la diócesis de Cartagena-Murcia del año 1475 que recoge una larga serie de constituciones de sínodos realizados tanto en el siglo XIV como en el XV, proporcionándonos una amplia visión de la sociedad murciana bajomedieval ${ }^{5}$.

\section{LA SACRAMENTALIZACIÓN Y LA SUPERVISIÓN DE LA VIDA.}

Según las Partidas, para conosçer a Dios et ganar su amor todo cristiano conuiene que aya ensi dos cosas. La vna fe cathotica que deue creerla. La otra los sacramentos de santa Yglesia que deue reçebir, que bien asi commo el alma et el cuerpo es onbre conplido et Ihesu Cristo es onbre et Dio,s assi el que cree la fe catholica et reçibe los sacramentos de santa Yglesia ha el nonbre de Dios et es acabado christiano ${ }^{6}$. Era pues de obligado cumplimiento que el feligrés los recibiese. La Iglesia a lo largo del medievo fue consumando cada vez más el encuadramiento de la sociedad cristiana merced al monopolio de la administración de los sacramentos por parte de sus ministros, lo cual se desveló como un instrumento sumamente eficaz. En el siglo XIV ya se consideraba en diversas obras la idea de herejía como aquel comportamiento que negaba la doctrina romana en materia de sacramentos ${ }^{7}$. Según Emilio Mitre, la sacramentalización de la vida y de la muerte hay que entenderla dentro del contexto del medievo, ya que esta época supone el dominio completo de la liturgia. Europa era la civilización del gesto, donde éste alcanzaba una importancia singular. Liturgia y gestos adquirían todas sus

5 Este sínodo se encuentra en la Biblioteca Nacional, sección Manuscritos 13.658-92, y ha sido publicado por ORTUÑO MOLINA, J., Sínodo de la Diócesis de Cartagena (1475), Murcia, 2002.

6 Partida I, Título IV, preámbulo.

7 MITRE, E. Op.cit., pág. 95-96. 
dimensiones en los puntos clave de la vida a los que el hombre medieval se veía sometido desde su nacimiento por la Iglesia ${ }^{8}$.

De singular importancia para el cristiano era el bautismo. Introducía al recién nacido en la comunidad cristiana convirtiéndolo en miembro de un solo cuerpo que era la Cristiandad. Su importancia queda remarcada por el hecho de que el recién nacido, apenas ser alumbrado, era bautizado para evitar que muriese al poco tiempo sin haber entrado a formar parte de la comunidad. Por ello fueron frecuentes los bautismos intrauterinos o, incluso, se le bautizaba si había problemas nada más asomar un brazo o cualquier otro miembro sin saber cuál iba a ser el sexo del neonato. En este supuesto se usaba de la fórmula de bautizar con dos nombres al feto, uno de hombre y otro de mujer, ante el desconocimiento de lo que venía. Si no era caso de necesidad, el lugar obligatorio para bautizar a un niño/a era la Iglesia. De este requisito solían estar exentos los reyes, que podían bautizar a sus hijos en el palacio 9 . Desde el mismo momento de su nacimiento el recién nacido quedaba adscrito a una parroquia y era obligatorio que oyese la mujer parida la misa en la parroquia donde había sido bautizado, llevando al niño para presentarlo en comunidad. Y no lo podía hacer en otro sitio si no era con licencia del párroco ${ }^{10}$.

Las condiciones precarias de vida y el enfrentamiento con un medio hostil en el medievo hacían necesaria la protección de la familia y de los parientes para poder asegurarse unas mínimas condiciones de supervivencia ${ }^{11}$. Este sentimiento de protección que arropaba al individuo se manifestaba en la multitud de relaciones de pseudoparentesco (por ejemplo los padrinos) o vasallaje que ligaban al hombre con el resto de la comunidad. No obstante, la Iglesia en su intento por dirigir todos los movimientos y contactos del feligrés llegó a regular las relaciones interpersonales. Se patrocinó la idea de familia nuclear, pues era más fácil de controlar que las extensas parentelas artificiales que se creaban de manera innata. Se fijó que el recién nacido no tuviese más de tres padrinos y dos madrinas si era varón, y de dos padrinos y tres madrinas si era mujer, para apartar e arredrar los males e inconvenientes que desto se

8 Ibídem, págs. 128-129.

9 SÁNCHEZ HERRERO, J. Concilios provinciales y sínodos toledanos de los siglos XIV y XV, La Laguna, 1976, pág. 126.

10 Constitución LXXII del sínodo, folio 53r.

11 GUERREAU, A. Op.cit., pág. 216. 
siguen o pueden seguir ${ }^{12}$, entre ellos la facultad de reglamentar el matrimonio que estaba prohibido hasta el cuarto grado de parentesco.

El bautismo sólo se podía recibir una vez en la vida. El que se atrevía a tomarlo por dos veces se arriesgaba a no poder tomar las órdenes eclesiásticas o, si era clérigo, que las perdiese. Incluso si el que se bautizaba por segunda vez resultaba ser un prelado o alta dignidad se vería descompuesto de la dinidad et de las ordenes que auia así commo quien pasa mandamiento de santa iglesia ${ }^{13}$.

De la confirmación no aparece ninguna mención en los sínodos diocesanos murcianos, pero supone un sacramento de suma importancia. Era necesario, y obligatorio, crismarse los bautizados para ser verdaderamente cristianos. Suponía un acto de reafirmación. Según las Partidas, así como con el bautismo se limpiaban todos los pecados en la confirmación se recibía el Espíritu Santo que daba fortaleza para lidiar con el diablo ${ }^{14}$. Su importancia queda manifiesta por el hecho de que sólo el obispo o su vicario tenían la potestad para efectuar tal sacramento. Era necesario haber confesado antes de tomarlo, para estar limpio de ánima, y tal vez para muchos jóvenes suponía el primer contacto con este sacramento de la confesión que era de una relevancia notable, puesto que suponía informar a las autoridades eclesiásticas del propio comportamiento para que éstas actúasen en consecuencia.

Si bien podría parecernos que el sacramento más común y cotidiano era la comunión, por lo que hoy nos encontramos, no era así en la Edad Media. La gente no comulgaba semanalmente, ni mensualmente, que podría haber sido lo normal puesto que el domingo se asistía a la misa de forma obligatoria. La comunión tan sólo se realizaba una vez al año, generalmente por Pascua mayor ${ }^{15}$. Era obligatorio comulgar, aunque se debía de pedir de forma voluntaria y consciente, porque el hecho de no hacerlo suponía incurrir en pecado mortal, a menos que fuese por prescripción del propio sacerdote (guarda de abstinencia y ayuno). Tal era la carga simbólica del hecho de comulgar que el sacerdote estaba obligado quando [...] aliquem comunicat

12 Constitución LXXXIV del sínodo de 1475, fol. 70r.

13 Partida I, Título IV, ley IX.

14 Partida I, Título IV, ley XI.

15 "Item unusquisue chrsitanus vel cristiana si est in etate legitima tenetur ex precepto ecclesie saltem semel in anno scilicet in Pascha recipere corpus Christi et debet sacerdos hoc sacrementum dar evere petentibus et impetentibus denegare." Constitución CIV del sínodo de 1475 , fol $80 \mathrm{v}$. 
teneat gauseape sumenti ante pectus ut si caso ceciderit ostia vel aliqua particula non possit cadere in terram, chaveta sacerdos ut numquam porrigat sano vel infirmo ostiam non consecratam pro Christi corpore. Existía toda una parafernalia que aumentaba la carga simbólica aún más de la comunión ${ }^{16}$ : se recitaban una serie de oraciones como Corpus et sanguis domini nostri Jesu Christi conservet te in vitam eternam, Amen cuando se entregaba la hostia o In nomine Domini nostri Jesu Christi cuando se levantaba la copa. Incluso el crisma que se utilizaba para la liturgia debía de recogerse de la catedral y quemarse el viejo para que no se diese a ninguno, salvo que estuviese en artículo de necesidad y tuviese imperiosamente que ser crismado ${ }^{17}$. La jerarquía dentro de la Iglesia marcaba unas directrices muy claras que aseguraban el control de los elementos principales por parte de la catedral y del obispo.

La confesión facilitaba tener al feligrés vigilado, por lo que era necesario que siempre confesase en el mismo lugar. De ahí la prohibición de confesar en cualquier otra parroquia, salvo que el párroco estuviese enfermo. Debía de hacerse en lugar público, y mucho más si eran mujeres las que iban a confesarse $^{18}$. El párroco del lugar estaba obligado a tener una lista de todos los parroquianos que confesaban para que cuando llegase el momento de la muerte de uno de estos tuviese la certeza de la conducta correcta del difunto. Todos los domingos entre la septuagésima y Pascua se leían públicamente los nombres de aquellos que no cumplían con el mandamiento. Era una forma de escarnio público y de pedagogía al mismo tiempo ${ }^{19}$.

La penitencia suponía, después de todo un año de relajación, mortificarse para expiar los pecados cometidos para poder purificar y restituir el alma.

16 "Portet autem sacerdos publice honeste et honorifice ante pectus indutus superpelliceo et orario ad collum cum reverencia et onore in pixide et custodia deaurata aut calice aut ex hoc apud omnes fides et devotio augeatur precedentibus ministris cum lanterna luminibus et campanula etiam si locus vel civitas sit interdictus vel interdicta. Doceat autem populum ut quando levetur corpus Domini manibus sacerdots in altari et quando portatur ad infirmum omnes reverenter se inclinen flexis genibus eum adorantibus." Constitución CVI del sínodo de 1475 , fol. $81 \mathrm{v}$.

17 Constitución LXVIII del sínodo de 1475, fol. 51v-52r.

18 Constitución CIII del sínodo de 1475, fol. 80-80v.

19 Constitución CII del sínodo de 1475, fol. 79v-80r. 
Existían tres formas de penitencia: la solemne que se realizaba el primer miércoles de cuaresma ${ }^{20}$. La penitencia pública era otra manera de penitençia que se faze conçejera mente E esta es quando mandan alguno que vaya en romeria: o traya consigo palo codal: o escapulario o otra vestidura como de orden: o que traya fierro çeñido en el braço o enel cuerpo: o que ande desnudo: o en paños menores Otrosi llama penitencia publica aquella que fazen yaziendo ençerrado en monesterio o en otro lugar apartadamente que este ay toda su vida por pecado grande que fizo. Et por eso es dicha publica: por que deue ser fecha conçejeramente ${ }^{21}$. La tercera manera de penitencia era la llamada penitencia en privado llevada a cabo sólo con el párroco, quien individualmente tras escuchar la confesión daba la absolución. El feligrés veía su vida sometida a examen y corregida. La moralidad cristiana era guardada por estos clérigos de las parroquias, y su influencia en la comunidad era total pues conocían los secretos de cada uno de sus miembros. Empero, el comportamiento desviado de algunos fieles no podía ser absuelto por todos los párrocos. Existían una serie de delitos que tan sólo las máximas autoridades tenían potestad para redimir. Para evitar el desconocimiento de qué causas podían los clérigos locales tratar se confeccionó una lista con todas aquellas causas privativas al obispo. Como es obvio, resultaron los casos de mayor peligro de desviación (homicidios, sodomía, recepción de órdenes seglares en secreto, hijos ilegítimos, la usura... $)^{22}$.

20 "El primero miercoles de quaresma descalços et vestidos de paño de lana que sea vil y raez y traher las caras atierra baxadas con grande omildad: mostrandose enesto por culpados del pecado que fizieron et que han grand voluntad de fazer penitençia del: y deue ay estar conellos sus arcipreste et los clerigos delas yglesias donde son perrochanos aquellos que oyeren sus penitençias. et despues desto deue salir el obispo con los clerigos ala puerta dela yglesia aresçebirlos et meter los dentro rezando los siete salmos penitençiales estando los prestes et el obispo llorando et rogando a dios por ellos que los perdone et desque los salmos fueren rezados deuese leuantar el obispo dela oraçion et poner las manos sobre las cabeças de aquellos penitençiales et ponerles la çeniza enellas et echandoles el agua bendita et cobriendo gelas con çiliçio: et diziendoles estas palabras sospirando et llorando que assi commo adan fue echado del parayso assi han de ser ellos echados por sus pecados y estonçe deue mandar alos que ouieron orden de hostiario que los echen fuera della et echandoles deuen yr los clerigos en pos dellos diziendo vn responso". Partida I, titulo IV, ley XVIII.

21 Partida I, Título IV, Ley XX.

22 Constitución C del sínodo de 1475, fol. 77r-79r. Lista confeccionada por Fernando de Pedrosa en 1388 y que de nuevo retoma Lope de Rivas en 1475. 
La visión fatalista de la vida y la concepción de privación de todo tipo de placer mundano que alejase al individuo de la contemplación de la divinidad no tenía por menos que desdramatizar la muerte ya que está suponía una liberación de la carga del cuerpo y la existencia eterna junto al Creador, siempre que se hubiese obrado bien y con rectitud en el tan traído valle de lágrimas. Hablar de una sacramentalización de la vida conlleva hablar de una sacramentalización de la muerte ${ }^{23}$. El nacimiento suponía la entrada en una vida y la muerte la salida para entrar en otra, ambas por medio de sacramentos. La extremaunción suponía la culminación de la obra purificadora iniciada con la penitencia ${ }^{24}$. Para el hombre del medioevo, la muerte era una constante en el vivir diario, presente a cada momento y aún más desde mediados del siglo XIV en la que la Península y Europa en general se ven inmersas en una fuerte crisis debido a epidemias, guerras, caídas de rentas, etc. que consiguieron difundir por todo el continente el fantasma del hambre.

Era obligatorio y habitual para los clérigos su presencia cuando uno estaba a punto de morir, dado que eran los encargados de que el enfermo que estaba a punto de morir entrase limpio de alma y preparado para afrontar el Juicio Final $^{25}$. Existía la creencia de que el alma se podía salvar o condenar en el último momento, durante la agonía, y por este motivo se rogaba a la Virgen y a la Santísima Trinidad que, como intercesores requeridos, concedieran al enfermo una buena muerte y una intercesión favorable ante el Redentor ${ }^{26}$. Existió un cambio sensible a mediados de la centuria del XV por presentar la muerte más como una experiencia personal y privada en la que empieza a surgir el miedo. Ese temor responde a la concepción del Juicio Final, y que hace presentar al difunto con el liber vitae donde se anotan las obras cristianas y los pecados cometidos, tal como un libro de contabilidad 27 .

23 MITRE, E. Op.cit. pág.100.

24 Ibídem, pág. 104.

25 Constitución CV del sínodo de 1475, fol. 81r.

26 DIAZ IBÁÑEZ, J. El clero y la vida religiosa en Huete durante la Edad Media, Cuenca, 1996, pág. 71.

27 MOLINA MOLINA, A.L. y BEJARANO RUBIO, A. "Actitud del hobre ante la muerte. Los testamentos murcianos de finales del siglo XV" en Miscelánea Medieval Murciana, vol. XII, año 1985, pág. 189. 
Se avisaba a los parientes, familiares, cofrades y a la parroquia para que a toque de campana difundiese la noticia de la muerte del miembro de la comunidad. Paulatinamente se observa como el número de familiares y amigos se fue sustituyendo por los rezos de los frailes y clérigos. La Iglesia iba tomando el control del difunto ${ }^{28}$. Mientras que se amortajaba al difunto, los clérigos rezaban los diversos oficios acompañados de los asistentes al velatorio. El día de las exequias el cuerpo era trasladado hasta el lugar del entierro (cementerio, parroquia ${ }^{29}$ o monasterio/convento), lugar explicitado por el difunto en su testamento, quien podía incluso fijar el orden y composición del cortejo. Que duda cabe que suponía una importante ceremonia social que servía para resaltar el estatus del muerto ${ }^{30}$. A pesar de elegir el lugar de sepultura, era necesario dejar una cantidad, la cuarta funeral, para la parroquia donde vivía si acaso decidía enterrarse en un convento o monasterio ${ }^{31}$, ya que no se podía desligar tan fácilmente del lugar en el que había sido educado. Existían, también, una serie de causas por las que se carecía de sepultura eclesiástica ${ }^{32}$, tanto porque suponía haber retado a la fortuna, como el caso de los guerreros, o haber muerto estando excluido de la comunidad cristiana.

La proximidad o lejanía del sepulcro al altar suponía significar el nivel social adquirido por el difunto, y, claro está, eso se pagaba. Asimismo, se intentó por los grupos sociales más pudientes erigir importantes túmulos

28 Ibídem pág. 190.

29 Durante el siglo XV hay muchas demandas de sepulturas en las iglesias. Las que se demandan en la catedral necesitan la licencia del obispo o vicario y del cabildo en uno. En cualquier iglesia de la diócesis era necesario el permiso del obispo o vicario. Se fijaba al libre albedrío del difunto o de la familia la donación a la iglesia de una cantidad de dinero. De este modo quedaba permitida a la familia directa (línea derecha) del difunto poder enterrarse en el mismo lugar sin necesidad de renovar el permiso y sin necesidad de pagar nada. Constitución XXXVII del sínodo de 1475, fol. 28r-29r.

30 DÍAZ IBÁÑEZ, J. Op. Cit. Pág. 72.

31 Constitución XLI del sínodo de 1475, fol. 31 r.

32 "Qui in pugna, certamine, torneamento huiusmodi decesserint aut a pugna vulnerati evaserint adeo ut postea ex eo ipsos ab hac luce mirgrare contigerit etiam [...] Simil modo prohibemus sepeleri in cimiterio omnes hereticos, excomunicatos majori vel minori excomunicatione et interdictos et usurarios et raptores et predones manifestos quamvis tales usurarii poentientes moriantur dum tamen habeant unde satisfaciant et heredes satisfacere voluerint ac etiam omnes quos notrium est in pecccato mortali decessisse." Constitución XLVIII del sínodo de 1475, fol. 33v-34r. 
funerarios para perpetuar la memoria. Pero aquí se impuso la mentalidad medieval de estamentos sociales y se prohibió que se levantasen tumbas altas en las iglesias, porque además de que podían interrumpir la contemplación de la liturgia, estaba reservado, tal elemento funerario, para la realeza y para los prelados. Se debía guardar en cada uno su estado ${ }^{33}$. De igual modo, recogen las fuentes que si un extranjero moría debía ser enterrado guardando su condición ${ }^{34}$. A pesar de la intención de mostrarse humilde ante la muerte recibiendo los hábitos de las órdenes mendicantes, el hombre no podía abandonar su tendencia a reafirmarse ante el resto de la comunidad siempre que su nivel social se lo permitía, incluso hasta después de muerto.

Otro modo de ostentación social vinculado con la muerte lo encontramos en la cantidad de misas que los difuntos dejaban encargadas en sus testamentos. La Iglesia mandaba que los cabezaleros cumpliesen íntegramente con los encargos, puesto que de ello se derivaban muchos beneficios ${ }^{35}$. Precisamente, fueron las órdenes mendicantes las principales difusoras de la idea del purgatorio y de la necesidad de realizar plegarias para la salvación del alma durante su estancia en el mismo. Las misas que más abundaban eran las realizadas durante el primer año de la defunción, es decir, aquellas que se celebran nueve días después del óbito, treinta días y en acabar el año de duelo. Según Chiffoleau, estas misas son fáciles de explicar puesto que suponían los segundos funerales, que se repetían hasta estar seguros de la "muerte definitiva" del difunto que se lograba cuando el cuerpo se transformaba en esqueleto ${ }^{36}$.

Las misas se transformaron en una mercancía que se compraba y que salvaron, en gran medida, la economía de la Iglesia. En parte, el delirio por tanta misa se produjo porque el hombre comenzaba a medirlo todo y las devociones también adquirieron una forma contable ${ }^{37}$. La importancia del

33 Constitución XXXIX del sínodo de 1475, fol. 30r .

34 Constitución XXXVIII del sínodo de 1475, fol. 29-29v.

35 Constitución XXXIV, fol. 25r-26r.

36 CHIFFOLEAU, J. "Dels ritus a les creences. La pràctica de la missa a l'edat mitjana" en Avenç, nº 111, año 1988, pág. 46.

37 Este deseo de contabilizarlo todo se pone en relación con los avances en la cartografía y la expansión del cálculo que tiene lugar en el siglo XIII en Europa que influye en la mentalidad de tal manera que aplica la contabilidad a todos los aspectos. En este sentido le lleva a poner en relación el tiempo vivido en pecado venial en la tierra con el tiempo que debe pasar en el purgatorio. Surge la idea de un infierno "temporal" que hay que medir y controlar. LE GOFF, J. El nacimiento del purgatorio, Madrid, 1986, págs. 262 y ss. 
valor económico adquirido nos lo pueden aportar las disputas surgidas entre las parroquias para decir las misas dejadas por los difuntos, si estos habían muerto y sido enterrados en otro lugar que no era su parroquia habitual. En este supuesto, generalmente, se dividían las misas entre las dos parroquias ${ }^{38}$.

Los sacramentos suponían puntos de observación del vivir cotidiano del ciudadano, y también del morir, que gracias al proceso de catequización e inculcación ideológica que la Iglesia llevó a cabo fue practicada por la mayoría de la población. Pero ello no quita que todos los sacramentos fuesen aceptados en igual media por el pueblo. De hecho, su continua repetición en los sínodos puede significar un cierto grado de incumplimiento por el pueblo. Ante la no-observación de tales preceptos la Iglesia contaba con sus armas coactivas de gran relevancia para la comunidad: el entredicho y la excomunión. La pena de excomunión era entregada por una carta del prelado, del vicario general o de cualquier otro oficial a los rectores de las iglesias, que se veían en la obligación de publicarla todos los domingos en misa ${ }^{39}$. De nuevo esto servía de escarnio y pedagogía, ya que el resto de la comunidad comprobaba qué cosas no podía realizar puesto que suponían quedar fuera de la comunidad, hasta el punto de no poder desempeñar oficios públicos ${ }^{40}$. No se trataba solamente de una pena religiosa, sino también civil.

En tiempos de entredicho la vida religiosa se paralizaba en la localidad. El clérigo que conscientemente celebraba o hacía algún oficio en lugar de entredicho perdía el beneficio y no podía ser absuelto salvo por el Papa, a menos que tuviese privilegio para poder efectuar la ceremonia ${ }^{41}$. Sin embargo, sí que se podía dar el bautismo y la confirmación. La comunión se daba a los que estaban agonizando, pero aún así no podían ser enterrados en sagrado, y sólo lo podían hacerlo aquellos clérigos que habían guardado el entredicho. La misa era celebrada a puerta cerrada y sin tañer de campanas para los clérigos, y tan sólo el día de Navidad, la Resurrección de Pentecostés

38 Constitución XXXVI del sínodo de 1475, fol. 27v-28r.

39 Constitución CIX del sínodo de 1475, fol. 83v-84r. La publicación dominical no cesaba hasta que era dada una carta de absolución del mismo juez que había dictado la excomunión. Tras esto, el nombre del perjudicado era sacado de un memorial donde estaban reseñados todos aquellos condenados. Por el trabajo de escribir los nombres, el párroco era premiado con cinco dineros al año.

40 Constitución CXII del sínodo de 1475, fol. 85v-86r.

41 Constitución CX del sínodo de 1475, fol. 84r-84v. 
y la Asunción de la Virgen se realizaba a puerta abierta sin dejar entrar a los excomulgados ni a los que les daban ayuda o consejo. En este tiempo la comunidad veía paralizada el transcurso normal de su vida, sintiéndose desamparados y excluidos de una sociedad que exigía la obediencia. Por ello no dudaron en dirigirse a otras instancias, como la Corona, para que intercediese por ellos ante las autoridades eclesiásticas a fin de lograr la conmutación de la sanción. Resultaba arriesgado estar fuera del orden.

\section{LA CATEQUESIS Y LA FORMACIÓN DEL CRISTIANO.}

La formación del cristiano se iniciaba nada más nacer con el acto del bautismo. A partir de ahí recibiría a lo largo de toda su vida, hasta el último momento, un adoctrinamiento constante que le llevaría a comportarse y a pensar como un cristiano. Las jerarquías eclesiásticas fueron conscientes de la necesidad de la formación del individuo y de ahí su preocupación en las constituciones de los sínodos que celebraban. Existía una preocupación por parte de la Iglesia hacia el desconocimiento que pudiesen tener los fieles de la materia religiosa, aunque tan sólo fuesen los pilares básicos necesarios para mantenerlos dentro de la ortodoxia y del pensamiento oficial. Se partía de la poca formación del pueblo llano que desconocía por completo el latín, la lengua oficial de la Iglesia y principal vehículo de comunicación de Roma con todas las otras iglesias de la Cristiandad, por lo que se hacía necesario que toda la materia que debía ser conocida por el pueblo estuviese expuesta en romance en unas tablas ${ }^{42}$. Al mismo tiempo se ordenaba que se conservase por escrito, con lo que se aseguraba la permanencia y la inalterabilidad del texto y su difusión homogénea.

Tan sólo nos ha llegado a lo largo de todos los sínodos de la Edad Media en la diócesis de Cartagena un breve catecismo que se inserta al principio de las constituciones que recibió la Iglesia de Cartagena del cardenal de Santa Sabina proclamadas en el concilio nacional de Valladolid de 1322, y que el obispo Juan Muñoz recoge en el sínodo que celebró en 1323. Es un breve catecismo que recoge los elementos fundamentales que debe conocer el cristiano y que conforman la base de su fe y costumbre. Según el catecismo,

42 Lope de Rivas, al igual que muchos otros obispos antes, es consciente de tal hecho y por ello manda "ut qualibet rector parrochialis ecclesie in scriptis habeat in latina et vulgari lingua articulos fidei, precepta, decalogi, sacramenta ecclesie, species vitiorum et virtutum ac etiam aliquem tractatum per confessionibus audiendis". Constitución VII del sínodo de 1475, fol. $5 \mathrm{v}$. 
la fe se define simplemente como la creencia de los artículos, de los sacramentos, guardar y acatar los mandamientos de la ley divina, realizar buenas obras y llevar una vida virtuosa alejándose de los pecados ${ }^{43}$. La actividad de un creyente se reducía a obedecer los dictados.

El catecismo no se escribía para los fieles, sino que se redactaba para el conocimiento de los clérigos que debían recitarlo en misa al menos los días de Navidad, Pascua mayor, fiesta de Pentecostés, Santa María de agosto y todos los domingos de cuaresma ${ }^{44}$. Posteriormente se añadiría para los niños las escuelas-catequesis, junto a la de gramática. Toda la labor catequística se completaba con las cartas pastorales, la explicación del evangelio y la confección de unas tablas que se debían exponer en lugar visible dónde se recogía un pequeño resumen del catecismo, que se encontraba en latín y en vulgar $^{45}$, como dijimos. Aún así, la ignorancia del pueblo era bastante grande en materia de religión, como lo atestigua el arzobispo de Toledo, Carrillo 46.

La predicación se convirtió en otro elemento fundamental para la formación del cristiano. Los siglos bajomedievales vieron como a lo largo de toda Europa las nuevas órdenes reformadas de franciscanos, dominicos y agustinos mandaban a sus miembros a las ciudades a que conviviesen con los ciudadanos e intentasen corregir sus vicios mediante la predicación directa en las plazas e iglesias. Hubo casos en que la llegada de algún predicador famoso trastornó la vida cotidiana de la ciudad, provocando un fervor religioso desconocido u olvidado. Fue el caso de la ciudad de Murcia, que recibió en 1411 la visita de san Vicente Ferrer, que dejó honda huella en las gentes sencillas y clérigos de la ciudad. La predicación servía para inculcar pautas de comportamiento cristiano, y por ello se contó con el apoyo de las instituciones

43 BE, L-II-9, fol. 5 r.

44 Íbídem, fol. 7r.

45 SÁNCHEZ HERRERO, J. Concilios provinciales y sínodos toledanos..., pág. 45.

46 "Entre las otras cosas que los Padres son tenidos a faser por sus fijos, son principalmente tenidos los faser instituir e enseñar las cosas que son necesarias para salud de sus animas e buena gouernacion dellos mismos, e porque conoscemos por experiencia que por defecto de maestros e de enseñadores los niños y otros mas altos deuen de aprender e saber las cosas nescesarias a los christianos e quedan con tanta inorancia que apenas se pueden llamar christianos ni ombres." Constitución 5 del sínodo celebrado en Alcalá de Henares el 10 de junio de 1480, recogido en SÁNCHEZ HERRERO, J. Concilios provinciales... pág. 305. 
civiles que veían una vuelta al orden ${ }^{47}$. Desde el púlpito se lograba conformar un espíritu colectivo, un sentimiento de comunidad importante.

La mayoría de los sermones giraban en torno al temor a Dios, al Anticristo y a la llegada del Juicio Final. Ello servía de base para criticar el comportamiento, los vicios y la relajación de las costumbres del pueblo. San Vicente en sus predicaciones perseguía el hecho de que se acudiese a los sorteros o adivinadores para curar enfermos, vaticinar o provocar partos, hallar objetos extraviados, pedir consejo, conseguir amores...porque ello contravenía el mandamiento de creer en un único Dios ${ }^{48}$. Otra persecución del santo fue contra aquellos que blasfemaban, los que no respetaban las fiestas de guardar, los que iban a la taberna en vez de ir a la Iglesia, o abandonaban el sermón a mitad. El juego de los dados estaba muy perseguido por los predicadores ya que incitaba al robo, al homicidio, al préstamo y a la blasfemia. La lujuria era denostada y criticada. Lujuria que también condenaba en los clérigos, que cometían este desvío y otros como el no asistir a los rezos y horas canónicas obligatorias, no cuidar su indumentaria u otras muchas cosas ${ }^{49}$.

Debido a la importancia que suponía la predicación y el efecto que provocaba sobre los fieles, que se dejaban llevar por los predicadores, el episcopado intentó controlar a tales predicadores ordenándoles que portasen una autorización del obispo, o del vicario en su defecto, para asegurarse de que a los parroquianos no se le ofrecían mensajes distintos que pudiesen producir desviaciones heréticas en su comportamiento ${ }^{50}$, ya que eran multitud los visionarios que fingían ser santones y predicaban por las villas y ciudades sin el menor conocimiento de teología difundiendo ideas que rayaban en la heterodoxia. Igualmente, preocupaba a las autoridades diocesanas que la

47 Es importante reseñar que durante su estancia en el reino de Murcia fue reclamado por los diversos concejos, entre ellos el de la capital, porque veían en los sermones un medio para "un reajuste o delimitación social, económica y espiritual, así como también una educación en diferentes frentes que afectaron, sin duda a las mentalidades" MOLINA MOLINA, A.L "Sermones, procesiones y romerías en la Murcia bajomedieval" en Miscelánea Medieval Murciana, vol. XIX-XX, año 1999-1996, pág. 222.

48 BE, L-II-9, fol. 6r.

49 NARBONA VIZCAÍNO, R. Pueblo, poder y sexo. Valencia medieval (1306-1420). Valencia, 1992, págs. 85-96.

50 Constitución IV del sínodo de 1475, fol. 4-4v. 
gente acudiese más a los predicadores que a las parroquias, donde podían ser adoctrinados por párrocos que dependían del obispo. Por ello, se pretendió, y para evitar conflictos entre los propios mendicantes, que cada orden tuviese un día y lugar para predicar en las parroquias, pero siempre con la salvedad de que debían ceder la voz al prelado si este decidía dar algún sermón ${ }^{51}$.

A lo largo del año, además de los domingos, existía una serie de fechas señaladas en las que el buen cristiano debía guardar descanso ${ }^{52}$. La Iglesia controló el tiempo anual reseñando tales fiestas que, generalmente, se adecuan al ciclo agrícola. El mayor número de fechas se concentra en primavera y verano, de tal manera que permiten al campesino tener días de asueto entre las duras y largas jornadas de trabajo en el campo. En estos días, y el domingo por ser el día del Señor, estaba vedado el trabajo, tanto el artesanal como el agrario, nisi urgene necessitatis vel evidenti pietatis causa et hoc de licencia sui sacerdotis. Incluso los judíos y musulmanes que no tenían por qué celebrar la festividad se veían imposibilitados de hacer manifestación pública de sus oficios, so pena de ser fuertemente multados. Pero estos días no eran solamente para el descanso preceptivo por las labores acometidas sino que eran fundamentales en tanto que era en esos días cuando el fiel tenía obligada su asistencia a la misa, donde era adoctrinado y controlada su presencia. Tan importantes eran tales oficios religiosos que no podían ser interrumpidos por cualquier sepelio, salvo excepciones ${ }^{53}$. La asistencia era necesaria porque era

\section{Constitución LIII del sínodo de 1475, fol. 6r.}

52 En el sínodo de 1475 Lope de Rivas fijó los días festivos: "Quare festivitatis colendas necesario subnotavimus [...] Primo Nativitais Domini nostri Jesu Christi, Stepani protomartyris, Joannis Apostoli et evangeliste, Circumcisio domini nostri Jesu Christi, Ephhiphania domini, Purificatio Virginis Marie, Mathie apostoli, Annuntiatio Virginis Marie, Marchi evangeliste, Philippi et Jacobi Apostolorum, Inventio Sancte Vía, Barnabe Apostoli, Nativitas Sancti Joannis Baptiste, Petri et Pauli Apostolorum, Marie Magdalene, Jacobi Apostoli, Transfiguratio Domini, Laurentii martyris, Assumptio Virginis Marie, Bartholomei Apostoli, Nativitas Virginis Marie, Mathei Apostoli, Michaelis Archangeli, Luche evangeliste, Simonis e Jude Apostolorum, Omnium Sanctorum, Andree Apostoli, Concepcio Virginis Marie, Thome Apostoli, Resurrectio Domini cum duobus diebus sequentibus, Ascensio domini, Pentecostés cum duobus sequentibus, Corpus Chisti”. Constitución XII del sínodo de 1475, fol. 7v. Sobre este tema consúltese el artículo de MARTíNEZ CARRILLO, $\mathrm{M}^{\mathrm{a}}$ Ll. "Fiestas ciudadanas" en Miscelánea Medieval Murciana, vol. XVI, págs. 9-50.

53 "Neque talibus diebus aniversaria vel exequie ab memoriam jam sepultorum defunctorum capitulariter celebrentur in ecclesia eadem nisi forsan pro Papa, cardinali vel episcopis aut pro rege vel regina eorum vel filiis vel alia potenti vel magna persona." Constitución LIX del sínodo de 1475, fols. 44v-45r. 
aquí donde se desplegaba todo el boato y el proyecto pedagógico destinado a concienciar al individuo para acatar una realidad social que le adjudicaba un orden en la sociedad, del que no era conveniente que saliese.

En la misa el clérigo podía llegar a alcanzar entre los fieles el máximo grado de respeto, e incluso de admiración. El establecimiento de normas muy detalladas para la celebración de las misas ${ }^{54}$ resulta un indicador de la importancia de la correcta celebración de la liturgia que, entre una de sus funciones, pretendía inculcar la idea de jerarquía y que servía para resaltar la importancia del estamento clerical sobre el resto de la sociedad ${ }^{55}$. Por ello se puso hincapié en que todos los clérigos ordenados in sacris, es decir, que habían tomados las órdenes mayores, debían, tanto si tenían un beneficio o no y todos aquellos que recibían un estipendio cualquiera de la Iglesia, ofertar la misa y estar en las horas canónicas, so castigo de realizar el doble de las horas que tenían asignadas ${ }^{56}$. Tenían la obligación de asistir a la misa para darle un mayor esplendor a la ceremonia. Por otra parte, era necesario que el texto litúrgico no tuviese errores ${ }^{57}$ y fuese igual en todas las partes del obispado ${ }^{58}$.

54 "Sacerdos habere debet scolarem in missa qui ipsum adjuvet quia illud officium solus facere non potest. In altari habeat lumen accensum dum missam celebrat juxta illud: Non offeres mihi sacrificium sine igne. Item habeat crucem cum celebrat quia in illo misterio passio Christi representatur. Corporale habeat album nullo colore tinctum nec presumat in corporali serico aut tincto celebrare sec in panno puro lineo albo al episcopo consecrato. Item prohibemus hostias de alio quam de puro et mundo et electo grano frumenti fieri et pane asimo non fermentato missa nisi cum vino puro de vite vino non aceto mixto cum aqua et in calice aureo vel argenteo de stagno non celebretur. Et calice magis de vino quam de aqua ponatur. Sacerdos vero verba canonis cum summa diligentia et solicitudine proferat ut non erret in eis nec reiteret ea. Item districtius prohibemus ne aliquis in peccato mortali constitutus misma celebret nisi prius confessus fuerit expresse et nominatim illud peccatum si sacerdotem invenerit cui valeat confiteri”. Constitución LXII del sínodo de 1475, fols. 46v$47 \mathrm{r}$.

55 ARRANZ GUZMÁN, A. "El clero" en Orígenes de la Monarquía Hispánica: Propaganda y legitimación, José Manuel Nieto Soria (dir.), Madrid, 1999, págs. 155-159.

56 "Et si illas vel illarum aliquam dimiserit emendet inhoris duplicatis vel in psalteriis recitaits cum sit debitum et tributum servitutis...". Constitución LXIII del sínodo de 1475, fol. $47 \mathrm{v}$.

57 Tal y como recoge la constitución LXIV era absurdo que el texto recogiese errores. Por eso se ordenaba desde el obispado que en un plazo de seis meses desde la publicación del sínodo (abril de 1475) para revisar los textos de la misa, de igual manera que se prohibía el 
Se unificaba la misa para obtener un mensaje igual en todo el territorio diocesano, una igual propaganda ante la ausencia e ineficacia de los medios de comunicación.

La asistencia a la misa como un rito obligatorio se instala lentamente entre los siglos XII y XIII, al mismo tiempo que se configura el monopolio parroquial de los principales sacramentos: bautismo y confesión. Era necesario que al menos asistiese un miembro de la familia, generalmente, el cabeza de familia, lo que reforzaba más la idea de una ceremonia de congregación y de socialización. Al menos, los padres de familia estaban presentes en el proceso de enseñanza de los elementos básicos de la cultura que tenía lugar en la parroquia y que luego transmitían al resto de su familia.

Se insistía mucho sobre el rezo y el aprendizaje de las cuatro plegarías fundamentales: el Padrenuestro, el Credo, el Ave María y el Salve Regina ${ }^{59}$. Además, se enseñaban unos gestos: agacharse en un cierto momento, inclinarse en otros ${ }^{60}$, etc. o cómo se debían de separar los hombres y las mujeres. Esa era la participación que solían adquirir los fieles en las celebraciones normales ya que no intervenían en ningún otro momento durante la realización de la eucaristía. Su actuación era pasiva, receptiva, sin interferir en ningún momento en el sacrificio. Para la mayoría de los parroquianos el rito central de la misa era la elevación de la hostia y no tanto la consagración, ya que no entendían en toda su magnitud el rito. Sin embargo, la elevación de la hostia estaba revestida de magnificencia y de realeza. No se tomaba la comunión, solamente se hacía una vez al año, por lo

uso de cualquier misal nuevo mientras que no se realizase una comprobación del mismo. fol. 48 .

58 Nicolás de Aguilar mandó unificar el rito, mandando que todas las parroquias copiasen el de la catedral como recoge Iluminado SANZ SANCHO en "La religiosidad del clero y del pueblo en los sínodos murcianos del siglo XIV" en Carthaginensia, vol. V, año 1989, pág. 88.

59 En Murcia se impone a principios del siglo XV la costumbre de que los sacristanes y curas enseñen estas oraciones y lo hace además por mandato del concejo que quiere continuar con la costumbre practicada por los monjes que acompañaban a fray Vicente Ferer en sus predicaciones. MOLINA MOLINA, A.L. La vida cotidiana en la Murcia bajomedieval. Murcia, 1987, pág. 125.

60 Durante la ceremonia se enseñaba a los feligreses a realizar una genuflexión o inclinar la cabeza en símbolo de respeto cada vez que el nombre de Cristo era pronunciado en las plegarias como el Te Deum. Constitución CVIII del sínodo de 1475. 
que la misa no tenía el significado de comunión sino más bien la misa del domingo servía para resaltar la unidad de la comunidad, el hecho de pertenecer a la Iglesia, a la sociedad civil, a la realeza de Cristo y, precisamente, por este reconocimiento de la realeza se hacía patente la sumisión a toda idea de autoridad ${ }^{61}$.

La solemnidad del acto que se celebraba, la necesidad de dotarlo de un marco idóneo que tuviese el suficiente aparato iconográfico y el boato $y$ grandeza requerido para tal fin, obligaba a que la celebración de la misa se tuviese que realizar en lugares concretos, siendo las iglesias o parroquias los lugares más adecuados. A ello se une el hecho de que el edificio tenía una jurisdicción aparte. Eran lugares sagrados donde ningún oficial real, concejil o señorial podía entrar de una forma violenta ni siquiera para la captura de malhechores refugiados en el templo. No obstante, al ser un lugar de congregación y de socialización popular no era de extrañar que el pueblo pusiese su aportación "pagana". Como lugar público que era, y donde se reunían en los días festivos, no tardaron en aparecer los bailes y las actuaciones que se celebraban, incluso, durante la ceremonia de la misa, lo cual distraía la atención de los fieles que no prestaban la suficiente atención al mensaje que se les pretendía dar. Tal acto de "rebeldía" no podía ser tolerado y pronto fue sancionado ${ }^{62}$, aunque su reiteración en las fuentes hace pensar en lo arraigado de la costumbre.

Pero la catequización del cristiano no se remitía solamente a la asistencia a la misa y a la predicación. Las obras de arte ${ }^{63}$, la iconografía, las fiestas populares, las cofradías... servían para reforzar el mensaje, ya se era consciente del poder de la imagen y de la representación para llegar a gentes de mentes simples en el que la lectura suponía un esfuerzo muy importante de abstracción.

Hubo fiestas de una fuerte carga significativa. La del Corpus era una de las fiestas más importantes del año, y se preparaba con esmero. Se fijaba con

61 CHIFFOLEAU, J. Op.cit. pág. 44.

62 "[...]in solemnitatibus missarum novarum dum divina aguntur ludi teatrales, larue, monstro expectacula necnon quam plurima inhonesta et diversa figmenta in ecclesiis introducuntur tumultationes quoque et turpia carmina et derisorii dicuntur." Constitución LXVI del sínodo de 1475, fol. 49r.

63 Estudio clásico, y de los primeros en este sentido, fue el realizado por G. DUBY en su estudio La época de las catedrales, Madrid, 1993. 
cuidado el itinerario de la procesión, se llevaban a cabo representaciones de juegos y misterios, etc. Después del pasacalles, un grupo de músicos y danzantes alegraban la jornada, llegando, incluso, a acabar la jornada celebrando una corriendo toros ${ }^{64}$. Eran celebraciones con una asistencia multitudinaria, por lo que no se podía desaprovechar la ocasión para adoctrinar al pueblo. La eucaristía se exaltaba en dicha procesión por las cofradías. Incluso podría verse en la celebración del corpus una pedagogía del poder ${ }^{65}$, puesto que se asemeja la ceremonia a la entrada triunfal del rey en una ciudad, o si se quiere Dios-rey. Todo el despliegue de la ceremonia vendría a remarcar la grandeza y sumisión al poder.

Las cofradías ejercieron una gran influencia sobre el pueblo cristiano, que buscaba en ellas refugio y sostén, proyectando su acción a toda la vida religiosa y social de la época ${ }^{66}$. Fueron un elemento fundamental para que la religión se implantase sobre la masa popular merced a que en las ciudades se convirtieron un elemento fundamental de integración de los individuos en la comunidad. Era una célula de socialización que prestaba a sus miembros protección y arropo social a cambio de fidelidad y acatamiento de los estatutos $^{67}$. Eran, pues, un híbrido entre una institución civil de asistencia, y una institución religiosa.

\section{MUJER, MATRIMONIO Y PECADO.}

El matrimonio obtuvo el carácter de sacramento en el siglo XIV como muestra de la importancia que tal acto adquirió para la Iglesia. Desde la Antigüedad había sido un rito privado de trascendencia solamente para la familia ${ }^{68}$. Conscientes las jerarquías eclesiásticas del valor de las relaciones

64 TORRES FONTES, J. Estampas medivales, Murcia, 1988, págs. 219-223, y MOLINA MOLINA A.L. La vida cotidiana en..., págs. 127-130. Sobre el mismo tema, es imprescindible la consulta de la obra de L. RUBIO GARCÍA La procesión del Corpus en el siglo XV en Murcia, Murcia, 1990.

65 CHIFFOLEAU, J. Op.cit., pág. 44.

66 PASCUAL MARTÍNEZ, L. "Aspectos religioso-culturales de la ciudad de Murcia" en en la España medieval, nº7, vol. 2, año 1985. Págs, 857-860.

67 ASENJO GONZÁLEZ, M. Las ciudades en el Occidente Medieval, Madrid, 1996, pág. 28.

68 G. DUBY fue uno de los primeros en tratar la importancia del matrimonio como institución en la Edad Media y el papel de la mujer en él dejado en su obra ya clásica $E l$ caballero, la mujer, y el cura, Madrid, 1981. 
familiares y matrimoniales, no dudó la Iglesia en arrogarse el papel de tutor de todo aquello que ocurriese en el seno de la pareja ${ }^{69}$. El matrimonio fue utilizado para el control biológico de la población, pues se reglamentaba una periodicidad determinada para los contactos sexuales: la abstinencia en tiempos de cuaresma, las fechas restrictivas en las que no se podían celebrar matrimonios, la prohibición de contactos carnales fuera del matrimonio, etc. Los períodos de abstinencia comprendían desde el primer domingo de Adviento hasta pasado todo el octavario de la Epifanía. Desde el domingo de la Septuagésima hasta el domingo de Quasimodo. Desde el lunes antes de la Ascensión hasta pasado el sábado de la semana de Pentecostés ${ }^{70}$. Además de ello, se prohibía que la ceremonia se convirtiese en una fiesta, que era lo tradicional, ya que deslucía lo sagrado de tal acto y le restaba el significado que la Iglesia pretendía darle. Refugiándose en los Padres de la Iglesia, los cánones conciliares reprochan la celebración de banquetes, actos lúdicos y bromistas en la celebración de la boda para evitar el insulto que podría producirse a la bendición solemne de la unión, intentando quitar todo resquicio a cualquier insinuación carnal a la boda ${ }^{71}$. Sin embargo, luchar contra esto fue difícil. Santo Tomás logró rehabilitar la actividad sexual en el matrimonio, exaltando su función de procreación a pesar de la presunta suciedad del acto. La procreación no suponía una mancha, y es más, la relación de amistad era necesaria entre los cónyuges para que la vida en pareja fuese mucho más llevadera. Pero el sexo seguía concibiéndose con el único fin de la reproducción, al menos para la mujer, y como un elemento accesorio de la relación. Se aconsejaba que en el caso de que la mujer fuese estéril el marido no la repudiase, debiendo la mujer permanecer en castidad pues era la mejor forma de matrimonio, según san Vicente Ferrer ${ }^{72}$.

Todavía en los siglos XIV y XV muchos matrimonios seguían celebrándose de una forma privada y lejos de las iglesias. La Iglesia obligaba

69 "Mas porque algunos arciprestes e vicarios e otros ombres non entendidos en derecho canonico algunas veces se entremeten de tractar e examinar peligrosamente aquellos, por esta constitucion defendemos firmemente que ninguno no sea osado cognoscer, finir nin determinar por sentencia diffinitiva estos pleytos matrimoniales nin sacrilegiales..." Constitución VI del sínodo de 1475, fol. 5v.

70 Constitución XI del sínodo de 1475 , fol. $7-7 \mathrm{v}$.

71 Constitución XIII del sínodo de 1475, fol. 8r.

72 NARBONA VIZACAÍNO, R. Op. cit., págs 98-109. 
a que la parroquia fuese garante de la legitimidad de la unión matrimonial porque, siendo el párroco el conocedor de todos los pormenores de los feligreses, no podía acceder a ignorar el acto tan importante de la unión matrimonial. No se podía celebrar un matrimonio fuera de la parroquia de uno ${ }^{73}$. Además, si no se contaba con licencia del obispo, que solía darla para los supuestos en que los magnates y hombres con poder y autoridad querían celebrar bodas en sus dominios, no podían realizarse bodas en las propiedades particulares; práctica tradicional como muestra de algo que había sido en sus orígenes un acto privado ${ }^{74}$. Oficiar un matrimonio clandestino resultaba bastante arriesgado y, más aún, si ya se habían mantenido relaciones sexuales entre los contrayentes, puesto que la pena de excomunión pendía sobre ellos y el cura que realizaba la ceremonia podía ser suspendido del oficio por tres meses y penado. Para que el matrimonio tuviese validez era necesario que tres domingos antes de la ceremonia fuese publicado en la misa la intención de los contrayentes de unirse en matrimonio para averiguar si había algún impedimento que no permitiese la realización del matrimonio, así como tiempo suficiente para que el párroco realizase sus indagación en aras a averiguar el grado de parentesco de los susodichos y otras posibles causas condenatorias para la no realización del matrimonio ${ }^{75}$.

La ceremonia asemeja mucho al rito de vasallaje que ya unos cuantos siglos antes se había institucionalizado para sancionar la relación entre hombres iguales pero con una clara diferencia entre ellos: el señor que recibe y el vasallo que se encomienda a su protección ${ }^{76}$. La boda tenía mucho de relación con esta idea, puesto que simbolizaba la unión libre de dos

73 " [...] ordinamus quod aliquis rector seu clericus parrochialis parrochianum alterius scienter in sua ecclesia ad matrimonium cum aparatu misse celebandum non recipiat seu admittat nisi super hoc assensum vel licentiam habuerit illius presbyteri seu clerici in cujus parrochia talis contrahens fuerit parrochianus." Constitución XLIX del sínodo de 1475, fol. $34 \mathrm{v}$.

74 Constitución LX del sínodo de 1475, fol. 45-45v.

75 Constitución LXXXIII del sínodo de 1475, fol. 69-69v.

76 LE GOFF nos analiza de una manera precisa la ceremonia del vasallaje en Tiempo trabajo y cultura (Madrid, 1983, págs. 331 y ss.) en la cual se puede comprobar el paralelismo entre el simbolismo de ambas ceremonias. 
personas ${ }^{77}$ en la que la mujer se encomendaba a la protección y servicio del marido a cambio de fidelidad ${ }^{78}$. A partir de ese momento la mujer adquiría un comportamiento pasivo en el hogar dependiendo del marido para cualquier decisión, que era el elemento activo y público de la relación.

La mujer es considerada en la Edad Media como un individuo incompleto. No se medía su personalidad sino su sexo ${ }^{79}$. Era un ser lujurioso y lascivo con una gran debilidad ${ }^{80}$, especialmente temida en las celebraciones lúdicas, como bailes y verbenas, en las que su naturaleza incitaba a caer en el pecado merced a sus movimientos y aderezos que realzaban su aspecto. Cada sexo tenía una proyección: el masculino la pública y el femenino la privada. Las repercusiones de esto suponía una gran carga para la mujer que veía como no sólo quedaba reducida al ámbito domestico o conventual sino que, además, tenía muy pocas posibilidades de desarrollarse intelectualmente y tener contactos con las corrientes de pensamiento y artísticas que la sociedad ofrecía $^{81}$. Incluso el uso de la palabra con el fin de exposición pública es sólo para el hombre, sea tanto oral como escrita, pues el silencio era el ornato de las mujeres.

77 Aunque de sobra es conocido que el acuerdo matrimonial era realizado entre las familias y en ocasiones resultaba más una transacción comercial. De ahí que las órdenes mendicantes se dedicasen a pedir limosna para poder configurar dotes con las que poder casar a mujeres desamparadas como único medio de que no cayesen en la prostitución, último resguardo para la supervivencia.

78 Actitud pasiva que llega incluso hasta condicionar la relación sexual. La Iglesia impone la postura del misionero durante el acto sexual como la única legítima en la que la mujer toma una actitud pasiva. NARBONA VIZCAÍNO, R. Op.cit., pág. 109.

79 MOLINA MOLINA, A.L. "La moralidad del clero secular murciano en la Baja Edad Media” en Homenaje al Profesor Juan Torres Fontes, Murcia, 1987. pág. 1.100.

80 La debilidad de la mujer estaba incluso defendida biológicamente por médicos de la época como Anthonius Guainerius o Juan de Aviñón, siguiendo este esquema: La mujer sufría una subida de útero (o mal de madre) que le provocaba histerismo (que deriva etimológicamente de la misma raíz que útero), ganas de procrear y fornicar. Este sentimiento le llevaba a la inestabilidad mental, a la irracionalidad y al peligro, por lo que era incapaz de desarrollar cargos públicos y debía estar siempre bajo la tutela de varones de su familia (marido, padre, hermano). A. MACKAY, "Apuntes para el estudio de la mujer en la Edad Media" en Árabes, judías y cristianas. Mujeres en la Europa medieval, Cella del Moral (ed.). Granada, 1993. pág. 18.

81 SEGURA GRAIÑO, C. "Mujeres públicas/malas mujeres. Mujer honrada/mujeres privadas" en Árabes, judias... pág. 58. 
La proyección doméstica se veía agravada por la idea de que la esposa era la guardiana del honor de la familia, constantemente sometida a los peligros de varones extraños que no tenían nada que perder en este tipo de aventuras amorosas, pues la honra no la perdían ellos ${ }^{82}$. La idea de guardiana del honor la llevaba a ser la más castigada en el caso de relaciones sexuales no regladas. Las uniones extraconyugales tenían un carácter pecaminoso y condenable para la Iglesia debido a que tendían a buscar el placer por el placer (algo que atentaba contra la idea de una existencia de privaciones y control en aras de una vida ultraterrena más llevadera). Se pretendía frenar toda búsqueda de placer que conllevaba embarazos no deseados y la consiguiente práctica de técnicas abortivas al discriminarse los hijos bastardos 83 . En el siglo XV rara vez aparece el término adulterio para referirse a las relaciones sexuales de los individuos casados fuera del matrimonio, pues el más utilizado es el de tener mancebas. Tanto si era la mujer la que engañaba al marido con otro como si era el marido el que mantenía relaciones con una mujer que mantenía a su costa, era ella la más criticada por la sociedad y las instituciones ${ }^{84}$. Una de las principales críticas que conllevaba la práctica del adulterio era el hecho de que el marido solía dedicar toda la atención a la manceba mientras que descuidaba a la mujer e hijos, que podían llegar a pasar penurias ${ }^{85}$. Además, en materia civil, resultaba una situación bastante conflictiva ya que la infidelidad solía llevar consigo bastantes altercados violentos acompañados de muertes, que siempre estaban justificados en caso de que el marido fuese el agraviado pero nunca en caso contrario.

82 José Enrique RUIZ DOMÉNECH en su obra La mujer que mira (Crónicas de la cultura cortés), (Barcelona, 1989) nos da una visión innovadora al comprobar como la mujer no siempre estuvo de acuerdo con su proyección social y va a ser la cultura cortés la que va a defender y reflejar en sus obras el anhelo de la mujer por su libertad. Sin embargo, el conflicto va a surgir entre lo que la mujer es en potencia y debería mostrarse en la realidad y lo que la realidad social le impone (págs. 110 y ss).

83 CÓRDOBA DE LA LLAVE, R. "Las relaciones extraconyugales en la sociedad castellana bajomedieval” en Anuario de Estudios Medievales, vol. 16, año 1986, pág. 575.

84 Ibídem, pág. 595.

85 " [...] toman e tienen concubinas públicamente e les tienen casas apartadas e se mantienen e viven e abitan e comen con ellas. Et acaece a las vezes que sus mugeres nin sus fijos no ternan lo que han menester”. Constitución XCI del sínodo de 1475, fol. 72v-73r. 
Sin embargo, el prostíbulo tuvo su lugar en las ciudades medievales. San Vicente Ferrer defendía la necesidad de tales lugares, precisamente por la "naturaleza perversa" de la mujer y la "flaqueza" del hombre. Era necesario un lugar donde todos estos malos humores tuviesen su salida, especialmente entre los jóvenes. Se acotaba un lugar para ello controlado por las autoridades civiles, y de este modo no se acababa con el mal pero se controlaba ${ }^{86}$. Todas las prostitutas debían de ser fácilmente identificadas para que no se confundiesen con las mujeres honradas y evitar, de este modo, malentendidos ${ }^{87}$. A pesar de lo dicho, se persiguió enconadamente el hecho de que cristianos yaciesen con judías o moras, al tiempo que no se permitía que prostitutas cristianas mantuviesen contactos con judíos o moros. En este supuesto rondaba la pena de muerte la más de las veces ${ }^{88}$.

\section{EL CLÉRIGO EN LA SOCIEDAD.}

La figura del clérigo es de suma importancia en la sociedad medieval, pues era quien velaba por el recto cumplimiento de todas las normas y vigilaba el comportamiento de cada uno de los vecinos. Por clérigo se entendía a todo aquel escogido en suerte de Dios, es decir, aquél encargado de loar a Dios y mantener un culto constante a lo largo del tiempo (por ejemplo las horas canónicas diarias). Por este motivo, debían estar mantenidos por el resto de la comunidad ${ }^{89}$. Sin embargo, el clérigo fue hombre de su época y participaba en cada uno de los vicios y usos de la sociedad que debía pastorear. La literatura sinodal abunda mucho en la figura del clérigo, pero nos deja un panorama muy sombrío del mismo porque nos lo presenta como un cúmulo de desafueros que había que corregir ${ }^{90}$. No debe asombrarnos, pues la

\section{NARBONA VIZCAÍNO, R. Op. Cit., pág. 116.}

87 Juan II, en 1422, ordenó "que todas las mugeres mundarias trayan un prendedero de oropel en la cabeça, ençima de las tocas de manera que paresca que sean consoçidas". TORRES FONTES, Estampas medievales, pág. 111.

88 MOLINA MOLINA, A.L. La vida cotidiana en ..., págs. 217-219.

89 Partida I, título VI, ley I.

90 Sobre todo nos encontramos este tipo de constituciones en el siglo XV, a fines, como preludio de un espíritu de reforma que empieza a vislumbrarse en la Iglesia, que siente la necesidad de corregir sus desvíos si se quiere dirigir una sociedad. Reforma que se vería acelerada tras el cisma surgido con la doctrina luterana en el siglo XVI. PASCUAL MARTÍNEZ, L. "Los sínodos de la Iglesia de Cartagena: siglo XV...”, pág. 200. 
naturaleza de la fuente induce a ello ya que se trata de un texto legislativo que, precisamente, intenta poner solución a los problemas y reglamentar la situación, y no pretende realizar una descripción del sujeto. Por lo tanto, no se debe pensar que el clérigo era solamente esto, sino que tenía una serie de virtudes y apelativos que en el sínodo no era necesario reflejar puesto que no se tenían que corregir. Por lo tanto, si queremos una visión completa de la figura del clérigo no podemos quedarnos tan sólo con lo que nos dicen los sínodos, y debemos acudir a fuentes paralelas de diversa índole, como cartas, actas capitulares, literatura religiosa, etc.

Los clérigos tenían conciencia de su posición de preeminencia en la sociedad, que se manifestaba en el hecho de pertenecer a una jurisdicción propia que los segregaba del resto de la comunidad y que, por lo general, resultaba mucho más apetecible que la jurisdicción civil (real, señorial, concejil...). Por ello fue frecuente que se infiltrasen en los obispados personas no conocidas que se hacía pasar por clérigos, no siéndolo, con la intención de conseguir los favores que ello conllevaba. Los falsos clérigos eran, las más de las veces, excomulgados, apóstatas, homicidas, etc. Con la intención de poner freno a estos desmanes, desde el obispado se ordenó que todo aquel que dijese ser clérigo debía tener carta confirmatoria de ello y se multaba pecuniariamente a aquellos rectores, clérigos, vicarios, etc. que permitían a extranjeros, que decían ser clérigos, ejercer el oficio sin antes haber mostrado la misiva requerida ${ }^{91}$. Los privilegios de los clérigos se reflejaban en su situación fiscal (exentos de multitud de impuestos reales y concejiles), inmunidad $\mathrm{y}$ franquicia frente a la justicia civil tanto personal como patrimonial, etc.

Pertenecer a la Iglesia significaba estar dentro de una estructura jerárquica, donde debían respetarse una serie de grados hasta ascender a lo más alto. Grados que marcaban una ascensión pero que imponían una obediencia. Existían nueve grados divididos en órdenes menores (corona, hostiario, lector, exorcista, acólito, subdiácono) y mayores o in sacris (diácono, presbítero, obispo). Según las Partidas, las órdenes menores debían de servir para

91 Constitución III del sínodo de 1475. Fol. 3v-4r. 
obedecer y observar cómo actuaban las mayores y apoyar en las tareas necesarias ${ }^{92}$.

Era frecuente que surgiesen discordias entre los clérigos y, por ese motivo, que apareciesen las conspiraciones y rencillas entre ellos. Pero las jerarquías eclesiásticas intentaron poner freno a tales altercados e imponer a los suyos que acudiesen a los tribunales propios de la Iglesia para resolver los asuntos. Se trataba de remarcar ese sentimiento de obediencia y pertenencia a una comunidad que controlaba la vida de todos sus miembros e imponía el respeto a la institución y obediencia a los instrumentos creados por ella misma para su propia perpetuación ${ }^{93}$. De especial relevancia eran las condenas dirigidas contra aquél, clérigo o laico, que se atreviese a conspirar contra el obispo, vicario general o cabildo ${ }^{94}$, máximos órganos de dirección de la diócesis.

Era imprescindible formar un lenguaje y una terminología que les permitiese ir creándose una imagen frente al resto de los ciudadanos que los diferenciase y dotase de un contenido simbólico que remarcase la posición tutelar del clero. El uso del latín, lengua que desconocía el resto de la comunidad en su inmensa mayoría, tenía una doble finalidad: el vehículo de unión de la Iglesia con todas sus provincias, de varias nacionalidades, y utilizar un código que nadie conocía y que permitía al clérigo ser el mediador entre el hombre y Dios. Por ello no dudaron en recurrir a las ocultaciones y al silencio para evitar el conocimiento del comportamiento poco digno de los miembros de la clerecía, al tiempo que intentaban mostrar una imagen pulcra del sacerdote. Desde mediados del siglo XV se aprecia una preocupación de reforma en el estamento clerical por parte de las propias jerarquías eclesiásticas para mejorar el comportamiento y preparación de los clérigos ${ }^{95}$.

92 "E esto fue fecho por tres razones. La vna porque assi commo los angeles loan a Dios sienpre enlos çielos que asemeiança desto loasen estos adios enla tierra: et la otra porque fiziesen sus ofiçios mas ordenada mente et meior. La otra porque auiendo y mayores y menores conosçiesen los menores alos mayores meioria et les fuessen obedientes et ouiesen su bien fazer: et los mayores que amasen asus menores seruiendose dellos et amparando los desu derecho". Partida I, título VI, preámbulo.

93 Constitución XCIV del sínodo de 1475 “decimos ser conspiradores e coniuradores contra la Iglesia de Carthagena e su libertad e obediencia e ser usurpadores de la justicia obispal e por tales deben ser punidos sin ninguna piedad e remission", fol. 74v.

94 Constitución XCVII del sínodo de 1475. Fol. 75v-76r.

95 ARRANZ GUZMÁN, A. "El clero...”, págs. 165-169. 
Todo debía comenzar por el aspecto exterior del clérigo, por su apariencia. Era necesario que el clérigo fuese reconocido a simple vista, que se reconociese su estado para evitar confusiones o engaños. Su oficio significaba estar en contacto directo con Dios por lo que se debía estar limpio de corazón $\mathrm{y}$, también, de cuerpo. Era imprescindible la moderación y parquedad en el vestir, exentos de cualquier adorno que pudiese distraer tanto al fiel como al clérigo de la devoción al Creador. Por lo tanto, no se les permitía llevar ropas decoradas con bandas ni de telas verdes, dorados, con mangas muy largas o cortas, etc. El material tenía que ser igualmente pobre, lana y no seda, aunque esta prohibición no afectaba a las jerarquías eclesiásticas 96 . A menudo, los clérigos gustaban de llevar armas, cosa que estaba prohibida salvo en tiempo de guerra o durante un viaje largo y peligroso, porque un clérigo no podía mancharse con la sangre de otro, tanto si era él quien amputaba como si firmaba la sentencia de muerte para un semejante ${ }^{97}$. No se permitía que un clérigo guardase luto por la muerte de un amigo o pariente, ya que su oficio le obligaba siempre a aspirar adornar la Gloria Divina, por lo que su vestimenta debía ser la reglada y no podía interferir la pena personal en algo que era necesario para toda la comunidad 98 . Pero, que duda cabe, la naturaleza humana se anteponía a la divina en este tipo de asuntos y, como muestras de dolor, descuidaban su aspecto dejando crecerse la barba y los cabellos, contraviniendo la obligación de afeitarse la corona y la barba por lo menos una vez al mes para que el cabello no les ocultase los ojos ni las orejas.

Todos los ordenados in sacris debían ser célibes ${ }^{99}$, el estado ideal de perfección, pero resultó muy complicado que los clérigos no cayesen en el

96 "Ceterum ne clerici in sacris ordinibus fuerint constituti aut beneficati extiterint sericum preter quam ab interiori futura clamidis aut capuciolorum que vulgariter forrature appellantur nec rubeas seu claras virides vestes induere aut caligas ejusdem coloris seu sotulares vel borzeguis rubeos nisi cum nigris desuper sotularibus dumtaxat calciare de cetero presumant”. Constitución XVIII del sínodo de 1475, fol. 11v-12r.

97 "Item sub poena excomunionis districte inhibemus ne clerici per se truncationes membrorum faciant aut judicent inferendas sanguis dictando vel etiam proferendo aut scribendo nec in loco in quo talia exercentur dum fiunt interesse presumant". Constitución XVII del sínodo de 1475, fol. 11r-11v.

98 "Quamvis omnis gloria aspirantium ad eternam salutem ab intus esse debeat verum quia militamus illi cum quo omnis pulcritudo agri est vilibus vestibus uti non debemus". Constitución XIX del sínodo de 1475, fol. 12r-12v.

99 SANZ SANCHO, I., "La religiosidad...”, pág. 61. 
pecado. Aquellos ordenados en órdenes menores no quedaban obligados por la norma y era usual que contrajesen nupcias, apareciendo en las fuentes de la época denominados clérigos conjugados. Eran civiles que se decidían a tomar las primeras órdenes (generalmente la corona) como medio de gozar de los privilegios que ello les confería ${ }^{100}$. Amparados en tal hecho cometían muchos desórdenes y homicidios convencidos de que su jurisdicción especial les solía proteger. Y en cierta medida debió de ser así, puesto que las constituciones sinodales requieren continuamente a los tribunales eclesiásticos que penalicen seriamente el comportamiento de estas gentes so pena de privar de su oficio a los oficiales de justicia ${ }^{101}$. Todos los clérigos conjugados estaban obligados a presentar en un plazo dado cartas de su condición de miembros de la clerecía para inscribirlos en un registro. De igual modo, debían llevar la corona rasurada del tamaño de un real castellano (dependía de la orden recibida las

100 Esta situación no fue muy bien vista por los poderes civiles que veían como iban perdiendo efectivos sobre quienes imponer la jurisdicción. Ejemplo lo podemos tener en el marquesado de Villena, donde don Alfonso de Aragón intentó evitar que vecinos del marquesado se abriesen la corona (fenómeno que era aprobado y favorecido por la Iglesia) ya que de este modo los diezmos de las heredades iban directamente a la Iglesia sin tener participación el marqués. (PRETEL MARÍN, A. y RODRÍGUEZ LLOPIS, M. El marquesado de Villena en el siglo XIV, Albacete, 1998. pág. 232). Por otro lado, ya comentamos como en la ciudad de Murcia existía un buen número de coronados. De ellos se conserva una lista (AMM. Cartulario Real. 1411-1429, fol. 41r) de más de cien personas del año 1415 , en la cual se nombran recogidos por colaciones y aparecen sin duda las familias más importantes de la ciudad (Calvillo, Cárlez, Riquelme, Sánchez Manuel, Jufré, Escarramad, Rodríguez de Junterón, Pujalte, Saorín, Puxmarín, Pérez de Ayala..., lo cual sirve de base para comprobar las interrelaciones existentes entre la nobleza local y la jerarquía eclesiástica, que nutre sus cargos con miembros de estas familias consiguiendo de este modo crear unas relaciones de pseudoparentesco fundamentales para los intereses mutuos y para la perpetuación del orden establecido.

101 "Ut prefertur delinquentes ad curiam ecclesiasticam propter privilegium clericale per seculares judices remissos debita animadversione prout qualitas exegerit delictorum punait et castiguet impunitos ver non relaxet absolvat vel abire permitat. Procuratores vero et fiscales qui ad accusandum hujusmodi clericos jura aut prelati proponunt si maliciose $a b$ accusando se subtraxerint vel negligentes fuerint aut quicumque dolo comserint quominus hujusmodi executio tolli aut impediri possit saltem vel diferri eo ipso ab officio suo sint privati alios arbitrio superiorum puniendi." Constitución XXI del sínodo de 1475, fol. 13v$14 \mathrm{r}$. 
dimensiones de la tonsura) y llevar unas ropas acordes con su condición de religiosos, especialmente en aquellas ceremonias en las que estaban obligados a asistir en el coro.

Los ordenados in sacris gustaban de tener mujeres en su casa para el servicio doméstico, resultando muchas de ellas barraganas con las que compartían cama y mesa. La predicación de Vicente Ferrer había lavado muchas conciencias e, incluso, parece que los clérigos convencidos de su mala actuación habían repudiado a muchas de estas mujeres del servicio doméstico. Existe, no obstante, un testimonio de protesta de unos clérigos que en representación del común de los mismos se quejaron ante el concejo murciano, todavía influido por la presencia del santo valenciano, porque habían sido sus casas registradas y expulsadas todas las sirvientas que vivían con ellos, acusadas de ser barraganas. Los clérigos protestaban porque éstas eran las mujeres que hacían de "sirvientas", quienes les ponían la mesa y realizaban las tareas domésticas ${ }^{102}$. Pero una constitución de 1475 nos sigue poniendo de manifiesto que los clérigos seguían gozando de los "servicios" de estas mujeres. Por ello, se intentó que los clérigos no vivieran con concubinas de una manera pública en su propia casa. Es curioso que el obispo diera dos meses de plazo para que los clérigos se deshicieran de ellas porque resultaba ser harto frecuente que los clérigos tuviesen mancebas, con las que además establecían fuertes relaciones sentimentales. Se castigó pecuniariamente (sobre las rentas del clérigo que recibe por su beneficio), y de forma progresiva, si el sujeto persistía en su actuación hasta el extremo de ser privado del beneficio y excomulgado. En el supuesto de no disfrutar de un beneficio quedaban imposibilitados para acceder a él o ascender a las órdenes superiores. Las mancebas no salían mejor paradas puesto que carecían de sepultura eclesiástica si morían en situación de concubinato ${ }^{103}$. En el alto clero murciano tenemos numerosos ejemplos de dignidades como los arcedianos Juan de Villagómez y Andrés de Onteniente, el deán Martín de Selva o el maestrescuela Fernán Sánchez de Mella, entre otros, que no tuvieron reparos en reconocer a sus hijos. Sin embargo, tras Trento se aprecia un cambio sustancial puesto que todas estas filiaciones fueron encubiertas por

102 MOLINA MOLINA, A.L. "La moralidad del clero secular murciano en la Baja Edad Media” en Homenaje al Profesor Juan García Abellán, Murcia, 1991, pág. 252.

103 Constitución XXIII del sínodo de 1475, fol. 15r-17r. 
la fórmula tío/sobrino o sobrina, llegando a falsificar documentos para ensombrecer tal hecho ${ }^{104}$.

También en el clero bajo se dieron estas relaciones y son numerosos los ejemplos. En los territorios de la Orden de Santiago eran bastantes los clérigos de las localidades, tales como Benatae, Letur, La Puerta y Villarrodrigo, que mantenían mancebas y los hijos nacidos de tal relación. Algunas uniones venían de largo, manteniéndose una vida totalmente marital, y en casi todos los casos nacía un hijo al primer año de iniciarse la relación y unos cuantos más después ${ }^{105}$. En Murcia capital tenemos el caso recogido en el acta capitular de 22 de enero de 1410 en la que los recaudadores se quejaban de que las mancebas de los clérigos deben pagar "pechos" al igual que el resto de los vecinos, pero que ellos no se atrevían a cobrarlos por temor a ser excomulgados por los clérigos ${ }^{106}$. En las Partidas queda recogido que ningún clérigo debía vivir con mujer que no fuese familiar próximo para poder evitar así las habladurías. Pero lo cierto es que el pueblo llano solía ser más benévolo que las jerarquías y tampoco daban mayor importancia (dentro de la mesura) al hecho de que el cura tuviese relaciones, ya que era algo muy normal y corriente. Tampoco era extraño que el clérigo tuviese hijos, ya que los hijos bastardos no tenían problemas para ser reconocidos, sobre todo para aquellas personas que no tenían hijos legítimos y no tenían a quien dejar la herencia ${ }^{107}$. Lo que no gustaba a la jerarquía eclesiástica era que el cura viviese en la casa con sus hijos, una vez que estos estuviesen ya casados porque la honestidad del clérigo se veía perjudicada al convivir en un lugar dónde existía trato carnal ${ }^{108}$. Del mismo modo, se veía dañada la imagen de la Iglesia si el cura era ayudado en la celebración del oficio por el hijo en el altar y las hijas o mancebas recogían las obladas y ofrendas. Al parecer esto

104 RODRÍGUEZ LLOPIS, M. y GARCÍA DÍAZ, I. Op.cit., pág. 63.

105 RODRÍGUEZ LLOPIS, M. Señoríos y feudalismo en el reino de Murcia, Murcia, 1986, págs. 102-103.

106 MOLINA MOLINA, A.L. La vida cotidiana ...pág. 200.

107 CÓRDOBA DE LA LLAVE, R. "Las relaciones extraconyugales...”, pág. 611 y ss.

108 "Statuimus et ordinamus ut nullus clericus beneficiatus in dicta nostra ecclesia cathedrali civitate et diecesi de cetero filium aut filiam seu filios aut filias conjugatos seu conjugatas intra domum in qua ipse moratur seu morabitur simul cum eo cohabitare permittat nec in aliqua alia domo sibi contigua, seu immedietate conjuncta" Constitución XV del sínodo de 1475 , fol. 9v. 
sí que producía grave scandalo en el pueblo, no solamente para menosprecio e odio de los disolutos clerigos mas aun ofusca el stado de la universal Iglesia e detrahe a la devoción de los fieles católicos ${ }^{109}$.

Todo clérigo beneficiado y ordenado en órdenes mayores tenía la obligación, salvo impedimento legítimo, de rezar las horas canónicas con devoción, tanto las nocturnas como las diurnas ${ }^{110}$. Pero esto no siempre se cumplía y en los oficios matutinos eran bastantes las bajas que se producían. Tuvo que idearse un sistema de recompensas que era distribuido entre los clérigos que asistían a los oficios ya que era la única manera de incentivarlos a pesar de las prescripciones episcopales ${ }^{111}$. Además, se dio el caso que muchos clérigos al alcanzar el grado de presbíteros rehusaban realizar oficios, de lo que amargamente se lamentaba el obispo, ya que eran precisamente los ordenados mayores los que debían dar ejemplo a los menores. Por ello, obligaba a estos presbíteros a realizar al menos cuatro misas anuales ${ }^{112}$. En ocasiones, su codicia les llevó al extremo de practicar la simonía, puesto que realizaban los sacramentos previo pago de honorarios. Hecho que venía de tiempo atrás puesto que ya desde el siglo XIV (concilio de Tarragona de 1329, sínodos de León de 1303 y Salamanca de 1335) se venía criticando ${ }^{113}$ porque los sacramentos debían ser ofrecidos gratuitamente.

Algunos clérigos preferían pasar su tiempo jugando a los dados, juego considerado impropio de la condición de un hombre de Iglesia (al igual que el baile público y la fiesta) ya que frecuentemente incitaba a la blasfemia y a la violencia entre los participantes ${ }^{114}$. Pero, sobre todo, porque los clérigos no

109 Constitución XVI del sínodo de 1475, fol. 10r.

110 SÁNCHEZ HERRERO, J. Concilios provinciales..., pág. 81.

111 "Statuimus et ordinamus quod quicumque beneficia hujusmodi perpetua in parrochialibus ecclesiis nostre diocecesis obtinentes seu loco eorum servientes in civitate, villa seu loco ubi talia beneficia existunt nisi alia legitima causa excusentur teneantur omni die ad missae principalis et vesperorum celebrationem in ecclesia divinis officiis interesse." Constitución XXIV del sínodo de 1475, fol. 17v.

112 Constitución LXIII del sínodo de 1475, fol. 48v.

113 MITRE, E. Op.cit., pág. 121.

114 "Cedit in opprobrium nostre religionis quod ministri ecclesie adeo vitam agüere inhonestam non verentur ut etiam ocium amplectentes in vilipendium sui ordinis se immiscunt ludis inhoneste ex quibus quanta perjuria, scandala, homicida et mala sequuntur nemo sane mentis ignorat." Constitución XX del sínodo de 1475, fol. 12v-13r. 
jugaban sólo por diversión sino, también, para obtener ganancias de las que conseguían muchos beneficios. Ganancias que solían usar para prestar a otros jugadores practicando la usura que tanto denostaba la Iglesia que se practicase ${ }^{115}$. Prestaban tanto frutos como dinero. En el caso de Toledo, estudiado espléndidamente por José Sánchez Herrero y extrapolable al ámbito murciano, los clérigos prestaban trigo, vino y aceite, esperando ganancias de la misma especie y en mayor cantidad, arrendaban bueyes, ovejas y otros animales mediante pactos contrarios a la justicia, esperando conseguir ganancias y quedando siempre bien asegurados. Concedían dinero adelantado a pobres labradores y mercaderes para que más adelante devolviesen pan, vio, pescado, paños, lana, ganados, hierros que ellos revendían obteniendo nuevas ganancias, etc. 116

El clérigo tenía la facultad de poder testar en quien el quisiese todos aquellos bienes adquiridos durante el disfrute de su beneficio y ganados en propiedad. A ello se sumó todos los frutos y rentas que tenía asignado el clérigo durante el año siguiente a su muerte ${ }^{117}$, que también pasaban a su heredero (de ahí que muchos clérigos no dudasen en reconocer a sus hijos nacidos del pecado), salvo el pie de altar que pasaba al clérigo que debía quedarse con el beneficio que dejaba el difunto.

\section{RELACIÓN DE LA IGLESIA CON LOS PODERES CIVILES.}

La Edad Media presenta una amalgama de jurisdicciones yuxtapuestas que provocaron situaciones de débil equilibrio en algunos momentos, dando lugar a altercados violentos y a acontecimientos desagradables. La cuestión radicaba en averiguar qué poder era superior al otro. Aunque los siglos pasaron y la teoría de las dos espadas quedó solventada, la problemática entre la Iglesia y el reino (poderes civiles, cuya cabeza la constituía la Corona) permaneció latente hasta bien entrado el siglo XVI. Existía una teoría sobre el poder directo que debía ejercer la Iglesia sobre el reino ya que los monarcas eran ungidos por los obispos para alcanzar la legitimidad y el carácter divino.

115 "Item statuimus quod clericus qui inventus fuerit fenus usurariorum exercere sortem et usuram amittat sic quod ipsa sors fabrice ecclesie carthaginensis aplicetur et usura suo remaneat debitori alias excomunionis sententis sit ligatus". Constitución XCII del sínodo de 1475, fol. $74 \mathrm{r}$.

116 SÁNCHEZ HERRERO, J. Concilios provinciales..., págs 95-102.

117 Constitución XXXI del sínodo de 1475, fol. 23-23v. 
Por este hecho, la Iglesia consideraba que su autoridad y poder era más importante que el desempeñado por las autoridades civiles, pues aquél legitimaba a éste. Sin embargo, la teoría del poder directo tuvo menos predicación que la del poder indirecto. Se afirmaba que el papa, la Iglesia, no tenía poder temporal por encima del rey y que los clérigos tenían exención fiscal y jurisdicción especial gracias a la donación de los reyes. Se defendía el hecho de que la Iglesia podía aconsejar a los monarcas y otros poderes civiles en su quehacer en aras de conseguir unas leyes justas y cristianas que permitiesen la salvación espiritual de los cristianos-ciudadanos. Este poder, que podríamos llamar indirecto, tenía dos vertientes: inducir al rey para que actuase de una manera determinada (aspecto directivo), u otra vertiente coactiva que suponía el punir con penas espirituales la actuación contraría a los designios de la Iglesia118. La verdad es que ambos poderes solían participar al unísono puesto que en definitiva lo que se conseguía con ello era el mantenimiento de un orden social que beneficiaba tanto al poder civil como a la Iglesia.

Para el siglo XIV murciano tenemos un bello ejemplo de esta colaboración de ambos poderes en la carta que dirigió el obispo don Guillén Gimiel al concejo murciano con motivo de un altercado surgido con el concejo oriolano, todo a raíz de la detención de un oficial del obispo al ir a tierras de Orihuela a reclamar impuestos. El enojado obispo lanzó excomunión al concejo que había permitido la detención y el entredicho a la localidad. En su pretensión de forzar la situación el obispo solicitó del concejo murciano que no permitiesen la entrada de ningún vecino de Orihuela en Murcia y rompiese las relaciones de todo tipo con el municipio alicantino. En dicho documento leemos e commo nos ayamos mester remedio e ayuda sobre este fecho de vos e de cada uno de vos, con la espada e braço seglar, e sodes tenudos de nos ayudar en ello de commo en derecho es contenido, ca es çierto que Dios todopoderoso ordeno dos poderes, uno espiritual, e otro temporal en la tierra porque se conpliese justicia por mano de los enperadores e de los reyes e de los otros que estuviesen en su lugar, ca estas son las dos espadas porque el mundo se mantiene, la una esperitual e la otra temporal, ca la esperitual e la otra temporal, ca la esperitual taja los males escondidos, e la temporal los

118 QUINTÍN ALDEA, Política y Religión en los albores de la Edad Moderna, Madrid, 1999, pág. 126. 
manifiestos, e destas espadas fablo Nuestro Señor Jhesuchristo el jueves de la cena quando pregunto a sus dezipulos [...] Ca si desacordasen e non se ayudasen vernien contra el mandamiento de Dios e avrian por fuerça a menguar la fe e la justiçia e non podia luengamente durar la tierra en buen estado nin en paz o esto se fiziese. E por ende, a nos conviene de por vos sobre esto seamos ayudados, porque con el vuestro esfuerço e braço, espada temporal, nos e las nuestras libertades de la nuestra Eglesia seamos defendidos 119 .

A pesar de esa colaboración hubo ocasiones en las que se produjo una violación de la inmunidad y de los privilegios de la Iglesia por parte de los concejos, monarcas y señores, que mediante el uso de la fuerza conseguían arrebatar riquezas e imponer vejaciones a los clérigos, puesto que el patrimonio eclesiástico era inmenso y fácil presa para aquellos que no fuesen temerarios de Dios. Este fenómeno se produjo en momentos en los que la situación social estaba impregnada por la violencia producida en coyunturas de crisis política y reajuste social, tal como ocurrió en Castilla en los siglos $\mathrm{XIV}$ y $\mathrm{XV}^{120}$. Ante esta situación la Iglesia intentó retener sus bienes mediante un exhaustivo control de sus propiedades, que tanto eran ocupadas por laicos durante los períodos de vacancia de un beneficio y esto solía ocasionar muertos y escándalos ${ }^{121}$ como por clérigos que vendían todo tipo de elementos destinados al culto divino y rentas de los beneficios sólo para uso y provecho propio ${ }^{122}$, lo cual iba en detrimento del patrimonio eclesiástico y, en definitiva, de su capacidad de reproducción.

119 TORRES FONTES, J. Estampas medievales, págs. 40-45.

120 Espléndido relato el escrito por Julio VALDEÓN BARUQUE para Castilla en el que analiza toda una serie de levantamientos populares provocados por la presión señorial. Los levantamientos sociales en Castilla. Siglos XIV y XV, Madrid, 1984.

121 "Quoniam nonnulli terrarum domini et eorum loca tenentes necnon clerici vel layci aliique inferioris fortune viri vere salutis immemores ne dum suis contenti metis manus suas extendere ad iniquitatem nin formidant ecclesias. Dei timore neglecto ut posesiones beneficiorum pro tempore vacantium seu vacare expectantium obtineant indebite occupant detinent et incastellant ipasque posesiones more venalium rerum vendunt et super ipsis indebite paciscuntur." Constitución XXVI del sínodo de 1475, fol. 18v.

122 "[...] ne rectores ecclesiarum nostre diocesis aut quicumque alius calicem, libros eclesiásticos, vestimenta sacerdotalia seu alia ornamenta eclesiástica aut res moviles, domos, terras, vineas seu quaslibet alias posesiones, redditus et censualia ad ipsas ecclesias pertinentia presumant vendere, dare, permutare, impignorare in emphiteosim sue a capitum 
Todo vecino, todo cristiano, podía ser convocado por un tribunal eclesiástico o por otro civil, debido a la doble condición de ciudadanocristiano. Teóricamente existían causas propias de los tribunales eclesiásticos como los crímenes contra la fe (herejía, magia), los juramentos, votos, simonía, sacrilegio, usura, blasfemia y cualquier otro referido a los sacramentos y cosas sagradas. Aunque la Iglesia procuró que los asuntos de materia religiosa ocupasen cada vez más el mayor espacio posible en la vida de los ciudadanos ${ }^{123}$. Ningún clérigo podía ser juzgado por tribunal civil ya que gozaban de su jurisdicción especial. Pero el fuero eclesiástico se podía perder por diversos motivos, entre los que destacaban aquellos que acogidos a jurisdicción eclesiástica ayudaban a los enemigos de la libertad de la Iglesia. También quedaban fuera los clérigos de órdenes menores, no beneficiados, etc, que no pagaban el catedrático como reconocimiento de la autoridad episcopal. Por último, los clérigos que sólo traían la corona y el hábito clerical como tapadera de sus acciones delictivas ${ }^{124}$ también se podían ver privados de sus privilegios.

Algunos jueces seglares no guardaban la libertad de la Iglesia y sus privilegios obligando a los clérigos a responder por las demandas interpuestas, principalmente por cuestiones de impuestos concejiles o reales de los que estaban exentos ${ }^{125}$. Al no parecer ante el tribunal el clérigo era condenado y realizadas las prendas pertinentes. Tenemos, pues, que el sacrilegio fue algo que estuvo al orden del día, sobre todo en períodos de crisis tanto política como económica, y que provocaba un reguero de abusos y

concedere vel quocumque alio modo alienare absque nostra licentia spetiali [...]" Constitución XXVII del sínodo de 1475, fol. 19v.

123 ARRANZ GUZMÁN, A. "El clero...”, págs 144-145.

124 CORTÉS DIÉGUEZ, M. "Relaciones entre los poderes civiles y las autoridades eclesiásticas en los textos sinodales (ss. XIV-XVI)" en Sínodos diocesanos y legislación particular. Estudios históricos en honor al Dr. Francisco Cantelar Rodríguez, Salamanca, 1999, pág. 176.

125 "Como los legos mucho sean infestos a los clerigos, la antigüedad lo dice y la spiencia de los tiempos presentes manifestamente lo declara. Ca no contentos de su poderio sfuerzanse en lo vedado e sueltan sus frenos a las cosas que a ellos no pertenecen. Et no parando mientes quanto les sea devedado el poderio en los clerigos e personas eclesiásticos e en los bienes dellos contra la eclesiástica libertad demandales pechos e collectas e facenles pagar en las imposiciones e sisas que echan en la carne, pan, vino e otras viandas, paño, ropas e joyas e otras qualesquier cosas, bien así como si los clerigos e personas eclesiásticas e sus bienes fuesen de su jurisdicción." Constitución LXXVII del sínodo de 1475, fol. 57v. 
crímenes cometidos contra los clérigos por aquellos que ostentaban el poder de las armas ${ }^{126}$, temerosos de los castigos espirituales sólo al final de sus vidas, cuando se vieran de frente ante la muerte.

\section{LAS MINORÍAS ÉTNICAS.}

No vamos a tratar aquí de hacer un estudio de mudéjares y judíos, de los cuales ya existen para Murcia espléndidos ejemplos, sino esbozar unos aspectos, pensamos que significativos, del vivir de estas gentes que se vieron a pesar de la protección concejil y real sometidos a una presión fiscal mayor que el resto de los vecinos de las villas, y acosados por un sentimiento de racismo que fue preconizado en gran medida por la Iglesia. Esto provocó que las minorías étnicas se viesen sometidas al descrédito personal y a las vejaciones, que si bien fueron posteriormente punidas por el concejo, no dejaron de demostrar cuál era el sentimiento de los cristianos hacia ellos.

Para los judíos resultaba necesario y ventajoso vivir en la ciudad, protegidos por los muros y por la institución concejil, ya que frecuentemente eran objeto de asaltos y maltratos ${ }^{127}$. Pero dentro de la ciudad vivían separados del resto de la comunidad en su aljama, que podía estar diferenciada del resto de la ciudad por una valla. Los ciudadanos eran los cristianos, y los demás debían vivir separados de la comunidad, segregados como elementos extraños, pero necesarios. Aparecen documentadas juderías en Murcia, Mula $^{128}$, Lorca ${ }^{129}$, Cieza y Librilla, correspondiendo la principal a la de la

126 "[...] avida informacion en como perversos hombres movidos con perversa e tiranica intencion contra la libertad eclesiástica con poco temor de Dios non dubdan de empescer en quanto podian a las personas e ministros de la Iglesia e prenderles e tomar e robarles los diezmos e bienes otros della e destroyr los lugares de las Iglesias e a las vezes las mesmas iglesias e monasterios, invadir, destroyr e quemar e los derechos dellos con osadia sacrílega en diversas maneras violar e quebrantar [...]", Constitución LXXIX, fol. 63v.

127 TORRES FONTES, J. "Los judíos murcianos a fines del siglo XIV y comienzos del XV”, en Miscelánea Medieval Murciana, vol. VIII, año 1981, pág. 64.

128 La judería de Mula va a existir con altibajos hasta el decreto de expulsión de los judíos en 1492. MENJOT, D. y GONZÁLEZ CASTAÑO, J. “ Les juifs de Mula au XVe siècle (notes socio-demographiques)", en Revue des Études juives, vol. CXLV (1-2), año 1986, págs. 28-30.

129 Como demuestra F. VEAS ARTESEROS en su obra Los judios de Lorca en la Baja Edad Media (Murcia, 1992), la judería lorquina no desaparece en el siglo XV tras las predicaciones de fray Vicente Ferrer sino que va a continuar e, incluso, a recuperarse a lo largo de todo el siglo $\mathrm{XV}$, debido fundamentalmente a su posición fronteriza y al importante 
capital. En estas villas y ciudades su función económica destacaba en el arrendamiento de rentas, oficios de menestrales, boticarios, físicos, banqueros, comerciantes...

Los sobrecogedores acontecimientos de 1391, que acabaron con la muerte de numerosos judíos y la destrucción de gran cantidad de aljamas en toda la Península, tuvieron una de sus pocas excepciones en Murcia, donde el concejo $\mathrm{y}$, sobre todo, el obispo Fernando de Pedrosa jugaron un papel fundamental en el respeto hacia la comunidad hebraica que sería posteriormente reconocido por el rey Enrique III ${ }^{130}$. No obstante, el paso del tiempo provocó que se produjera un cambio de actitud, cambio que vendría producido, en parte, por las predicaciones del dominico san Vicente Ferrer y por el cambio de actitud en la Corona manifiesta en la regente Catalina de Lancaster al publicar un ordenamiento muy restricto para judíos y mudéjares en 1411. Las predicaciones del santo calaron hondo en la sociedad murciana, al igual que en todas aquellas donde ejerció la predicación, y un sentimiento hostil se creó en la sociedad. La presión social llevó consigo multitud de conversiones movidas más por el espíritu de supervivencia que el de verdadera creencia. A menudo, la judería era visitada por el alguacil que abusivamente realizaba detenciones improcedentes con el único fin de obtener prendas. Todo judío que anduviese por la noche fuera de la judería era detenido, e incluso algunas veces en la propia judería, lo que provocaba la indignación de la comunidad hebrea ${ }^{131}$. Los insultos y abusos por la calle eran frecuentes aunque los judíos no dudaban en denunciar ante el concejo tales desmanes. La Iglesia potenció una política de segregación a pesar de valerse del uso de judíos para la gestión de sus bienes y obtener de este modo una mayor rentabilidad ${ }^{132}$. Los judíos gozaron de una libertad de acción que les convertía en verdaderos prestamistas y capitalistas con el dinero de la Iglesia. Además, recurrieron a ellos para la consecución de objetos de lujo gracias a sus contactos comerciales.

desempeño de las labores, tanto artesanales como financieras, llevadas a cabo por la comunidad hebraica.

130 TORRES FONTES, J. Estampas medievales, págs 47-51.

131 RUBIO GARCÍA, L. Los judios de Murcia en la baja Edad Media (1350-1500), Murcia, 1992, pág. 38.

132 MARSILLA DE PASCUAL, F. "Los judíos y el cabildo de Murcia en el siglo XV", en Miscelánea Medieval Murciana, vol. XV, año 1989, págs. 63 y ss. 
Los mudéjares del reino de Murcia sufrieron una disminución progresiva desde el momento de la conquista hasta 1500, con algunos períodos de cierta recuperación. La conquista aragonesa del reino murciano resultó muy perjudicial para la población mudéjar ya que vio sensiblemente disminuido su volumen de población. La disminución de su número llegó a ser tan alarmante y dañina para la producción de los campos de Murcia que los Reyes Católicos solicitaron el asentamiento de cinco mil familias en tierras murcianas ${ }^{133}$. Hacia la década de 1420 desaparecen aljamas de moros en Yéchar y Priego de Moratalla, hacia mediados de siglo Letur y Socovos y en el último cuarto de siglo Férez. Pero aún así pervivieron unas cuantas como las de Ricote, Pliego, Abanilla, Alcantarilla, Alguazas y Murcia. Al contrario que la comunidad judía los mudéjares predominaron en las villas y huerta, encontrando un refugio en las encomiendas santiaguistas. Este predomino en el campo empieza a experimentarse a mediados del siglo XIV, favorecido porque los propietarios de tierras en las huertas vieron en las poblaciones mudéjares una importante fuente de rentas. Así, por ejemplo, familias como lo Fajardo o los Ayala fueron quienes patrocinaron el asentamiento de mudéjares en la Puebla de Mula. Estas nuevas comunidades no se conformaron como señoríos jurisdiccionales ya que la población mudéjar estaba bajo la jurisdicción del concejo, pero sí dependían económicamente del propietario de la tierra, que tan sólo cedía el dominio útil ${ }^{134}$.

Los mudéjares eran de condición más baja que los judíos. Estaban protegidos por el concejo por mandato de la Corona, que los consideraba de su propiedad, y por la necesidad que tenía de ellos por sus servicios como mano de obra en la huerta. Un ejemplo de ello surgió cuando en 1405 la mayoría de los hombres de la capital trabajaban en las obras del alcázar nuevo de la capital quedando desatendidos la mayoría de los campos de cultivo. Ante este hecho, el concejo murciano hubo de recurrir a la población mudéjar para que trabajase los huertos circundantes prometiéndoles que no se producirían situaciones de abusos y toma de prendas ${ }^{135}$. Pero esa protección no fue

133 TORRES FONTES, J. "Los mudéjares murcianos en la Edad Media", en III Simposio Internacional de Mudejarismo, Teruel, 1986, pág. 62.

134 RODRÍGUEZ LLOPIS, M. "Población y Fiscalidad en las comunidades mudéjares del Reino de Murcia (siglo XV)", en III Simposio Internacional de Mudejarismo, Teruel, 1986, págs. 40-42.

135 TORRES FONTES, J. “Los mudéjares...”, pág. 63. 
suficiente y las vejaciones contra las mujeres fueron frecuentes por parte de los guardas de sacas y almojarifazgo que controlaban la entrada de mercancías a la ciudad, al tiempo que abusaban de los comerciantes mudéjares entorpeciéndoles su labor ${ }^{136}$. Si los cristianos les permitieron conservar oficialmente sus leyes, en la práctica no fue así porque se establecieron fuertes diferencias socio-económicas que relegaron a la población mudéjar a una situación de dependencia económica traducida en la conversión de esta población en mano de obra barata y explotada. Sólo en las encomiendas santiaguistas esta presión no fue tan intensa. Desde 1480, por un ordenamiento de los Reyes Católicos, fue obligatorio el llevar un distintivo que permitiese el reconocimiento de judíos y moros a simple vista. Significar a las personas de este modo resultaba una ofensa para la dignidad de los mismos ya que las burlas estaban a la orden del día. A ello se unía el pago de impuestos cada vez más numerosos como las derramas, el cabezaje, los servicios y las distintas imposiciones de guerra que se sucedieron en tiempo de los Reyes Católicos y que mermaron considerablemente las posibilidades económicas del mudéjar. Éste cada vez se vio más abocado al cambio de religión o la huída hacia Granada, donde la densidad de población no le aseguraba un mejor bienestar a pesar de estar con miembros de su misma $\mathrm{fe}^{137}$.

La Iglesia coadyuvó a la creación de ese sentimiento contra las minorías. La falta de formación de la gran mayoría de los cristianos provocaba que los ritos, costumbres y creencias de los judíos y musulmanes pudieran ser perjudiciales para aquellos, que no serían capaces de discernir problemas serios de teología derivados de la similitud doctrinal, dándose la posibilidad de caer en la herejía ${ }^{138}$. En su idea de universalidad, la Iglesia mantuvo el mensaje de infalibilidad que excluía de la verdad a los miembros de las otras comunidades aduciendo que andan en las tiniebras de error e no saben la claridad de la verdad. En definitiva, se trataba de inmovilizar a un sector de la población que no quedaba bajo el control ideológico de la Iglesia ni de su

136 TORRES FONTES, J. Estampas medievales, págs. 101-102.

137 MOLINA MOLINA, A. L. y VEAS ARTESEROS, Ma C. "Situación de los mudéjares en el reino de Murcia (siglos XIII-XV)", en Áreas. Revista de Ciencias Sociales, vol. 14, año, 1992, pág. 103.

138 SANZ SANCHO, I. "La religiosidad", pág.77. 
coacción. En su afán de traer al redil a la población se produjo una unión de intereses entre Iglesia y poder civil que quedó de manifiesto en la influencia de san Vicente Ferrer en las ordenanzas municipales posteriores de claro corte segregacionista.

Los sínodos no fueron una excepción y mostraron el miedo de que la religión musulmana pudiese influir en la población cristiana por lo que una de las medidas adoptadas fue prohibir que los hijos de cristianos queden bajo tutela musulmana ${ }^{139}$, así como la negación de asistir a bodas o a cualquier otra ceremonia ${ }^{140}$. Además, no estaba bien visto que las mujeres cristianas llevasen sirvientas musulmanas a misa, ya que solía provocar las risas y burlas de los congregados y distraía de la atención requerida ${ }^{141}$. Se limitaba el comercio con los musulmanes de aquellos elementos de suma importancia como caballos, metales, armas y alimentos de vital necesidad, condicionada esta limitación por la situación de guerra en que se vivía en aquel momento con Granada, intentando no facilitar recursos al enemigo ${ }^{142}$. Pero muchas veces el sentimiento de racismo era mutuo y estas minorías se retraían en su comunidad despreciando todo contacto que supusiese el trato con cristianos. Esto, obviamente, enconaba más los ánimos de los cristianos que reaccionaban de igual manera, pero con el agravante de que ellos estaban en posición dominante y contaban con la mayoría y el uso legítimo de la fuerza ${ }^{143}$. Llegó a existir el caso de excomunión dada a un judío, lo cual

139 “[...] mas porque acaece muchas veces que algunos fieles cristianos ponen sus fijos e sus nietos e sus parientes mozos en servicio de los judios o de los moros a soldada, por ende, porque las costumbres de los moros e de los judios non concuerdan en ninguna cosa con las nuestras, estos tales mozos diligentemente se pueden engañar por simplicidad del entendimiento e de la su secta tirar." Constitución LXXXVI del sínodo de 1475, fol. 70v-71r.

140 Constitución LXXXIX del sínodo de 1475, fol. 72-72v.

141 ARRANZ GUZMÁN, A. "Imágenes de la mujer en la legislación conciliar (siglos $\mathrm{XI}-\mathrm{XV}$ )", en Las mujeres medievales y su ámbito jurídico. II Jornadas de investigación interdisciplinares, Madrid, 1983, pág. 43.

142 Constitución LXXXVIII del sínodo de 1475, fol. 71v-72r.

143 Se dio el caso de que en el granero de Murcia perteneciente a la Iglesia los judíos elaboraban su propio vino, llamado caser, siguiendo sus tradiciones que no le permitía usuar objetos que ya usasen los cristianos. Ello provocó que los cristianos se enconasen y criticasen que los judíos realizasen el vino con el diezmo que ellos pagaban. La Iglesia prohibió que los judíos realizasen tal práctica. (ACM, B-1, fol. 54v-55v) Igualmente, las autoridades eclesiásticas prohibieron que los carniceros vendiesen a los cristianos animales muertos por judíos o musulmanes. Constitución LXXXVIII del sínodo de 1475, fol 71v. 
demuestra que sólo resultaba una pena canónica, sino que llevaba consigo consecuencias civiles importantes ${ }^{144}$, tales como que el individuo quedaba fuera de una sociedad necesaria y enteramente cristiana.

144 RUBIO GARCÍA, L. Los judios..., pág. 373. 